\title{
The Origin of Continental Carbonates in Andean Salars: A Multi-Tracer Geochemical Approach in Laguna Pastos Grandes (Bolivia)
}

\author{
E. Muller ${ }^{1}$, E. C. Gaucher ${ }^{2}$, C. Durlet ${ }^{3}$, J.S. Moquet ${ }^{1}$, M. Moreira ${ }^{1}$, V. Rouchon ${ }^{4}$, P. \\ Louvat $^{1}$, G. Bardoux ${ }^{1}$, S. Noirez ${ }^{4}$, C. Bougeault ${ }^{3}$, E. Vennin ${ }^{3}$, E. Gérard ${ }^{1}$, M. Chavez ${ }^{5}$, A. \\ Virgone $^{2}$, M. Ader ${ }^{1}$
}

${ }^{1}$ Université de Paris, Institut de physique du globe de Paris, CNRS, F-75005 Paris, France

${ }^{2}$ Total CSTJF, Avenue Larribau, 64018 Pau Cedex, France

${ }^{3}$ Biogéosciences, UMR 6282 CNRS, 6 boulevard Gabriel, Université Bourgogne

Franche-Comté, 21000 Dijon, France

${ }^{4}$ IFP Energies Nouvelles, 1-4 Avenue de Bois Préau, 92852, Rueil-Malmaison Cedex, France

${ }^{5}$ Total E\&P, 40 Calle Las Violetas, Edificio Arcus, Santa Cruz de la Sierra, Bolivia

Corresponding author: Elodie Muller (emuller@ipgp.fr)

\section{This article has been accepted in Geochimica et Cosmochimica Acta.}

\begin{abstract}
In continental volcanic settings, abundant carbonate precipitation can occur with atypical facies compared to marine settings. The (bio-)chemical processes responsible for their development and early diagenesis are typically complex and not fully understood. In the Bolivian Altiplano, Laguna Pastos Grandes hosts a $40-\mathrm{km}^{2}$ carbonate platform with a great diversity of facies and provides an ideal natural laboratory to understand the processes responsible for the precipitation of carbonates in a continental province dominated by volcanism. In order to trace the origin of both water and solutes in the lagoon, the major element and stable isotope compositions $\left(\delta^{2} \mathrm{H}-\delta^{18} \mathrm{O}, \delta^{37} \mathrm{Cl}, \delta^{7} \mathrm{Li}, \delta^{11} \mathrm{~B}\right.$ and $\left.{ }^{87} \mathrm{Sr} /{ }^{86} \mathrm{Sr}\right)$ of the spring and stream waters were characterized, as well as the stable isotope compositions $\left(\delta^{13} \mathrm{C}, \delta^{15} \mathrm{~N}\right)$ and noble gas isotope ratios of hydrothermal gases associated with spring waters. The results show that thermal springs discharging on the carbonate platform are close to saturation with calcite. PHREEQC modeling, together with fluid geochemistry and temperature estimated from a combination of geothermometers, indicate that $\mathrm{Ca}$ in these springs is inherited from the alteration of the volcanic bedrock by aqueous fluids heated at $\sim 225^{\circ} \mathrm{C}$ and enriched in magmatic mantle-derived $\mathrm{CO}_{2}$. Our results clearly show that the main driver for the precipitation of modern carbonates in Laguna Pastos Grandes is the deeply sourced $\mathrm{CO}_{2}$, which boosts the alteration of volcanic rocks at depth.
\end{abstract}

\section{Introduction}

It has long been documented that continental carbonates can form, in varying abundances, both in pedogenetic profiles (see synthesis in Zamanian et al., 2016; Durand et al., 2018) and in palustrine-lacustrine environments (see synthesis in Alonso-Zarza and Tanner, 2010; Verrecchia, 2007). Yet, their occurrences in continental volcanic provinces, typically 
dominated by volcanoclastic, bio-silica, clay or evaporitic sediments, have not been investigated as much as their marine equivalents, generally considered as common hydrocarbon reservoirs and traditional archives of past oceans since the Archean. The recent discovery of hydrocarbon plays in Lower Cretaceous continental carbonates off the Brazilian coast changed this paradigm (Terra et al., 2010; Tosca and Wright, 2015) and promoted several studies focused on the origin and occurrence of carbonates in continental settings where the catchment and underlying rocks are mainly volcanic (e.g., Teboul et al., 2016; 2017).

Laguna Pastos Grandes in southern Bolivia includes a $\sim 40 \mathrm{~km}^{2}$ carbonate platform making it unique among the more than 200 salars scattered across the volcanic Central Andes region (Fig. 1a, b). Laguna Negra in Argentina is the only other Andean salar recently described with a significant, but much smaller $\left(6.5 \mathrm{~km}^{2}\right.$; Gomez et al., 2014), carbonate platform. Laguna Pastos Grandes exhibits a great diversity of calcitic, siliceous and evaporitic fabrics deposited in palustrine to shallow lacustrine environments, including some of the largest modern pisoliths discovered to date (Fig. 1c; Risacher and Eugster, 1979; Jones and Renaut, 1994; Bougeault et al., 2019). In some ways, it may be considered as a modern equivalent of carbonate facies and processes that occurred during sedimentation of the Presalt facies in the volcanic-rich South Atlantic realm during the 58 Early Cretaceous.

59 Although several studies were conducted on the hydrology and origin of chemical 60 sediments in Bolivian and Chilean salars, a clear explanation for the abundance of modern carbonates in Laguna Pastos Grandes is still lacking. From structural, climatic and lithological points of view, Laguna Pastos Grandes seems to be similar to salars where carbonate precipitation is insignificant (Risacher et al., 2003; Risacher and Fritz, 2009; see geological setting). Indeed, while climatic parameters fundamentally control the existence and morphology of salars (Risacher and Fritz, 2009), the chemical composition of the brines and the nature of the precipitates in these lakes mainly depend on the initial composition of the inflow waters. In the present study, we thus performed a comprehensive geochemical study of gases and waters discharging on the carbonate platform of Laguna Pastos Grandes and of the brine filling the main basin.

The overarching goal of our research is to better understand the ongoing processes that allow for the rapid growth of these continental carbonates in a volcanic area under structural extension and fed by hydrothermal fluids. As a first step, this study focuses on the origin of the fluids and solutes from which carbonates have formed in the laguna based on the study of: (i) the chemical compositions of water samples from streams of the drainage area and hydrothermal springs upwelling through or near the carbonate platform and gas associated with the hydrothermal springs; (ii) the isotopic compositions of gas components $\left(\delta^{13} \mathrm{C}, \delta^{15} \mathrm{~N}\right.$ and noble gases), water samples $\left(\delta^{2} \mathrm{H}\right.$ and $\left.\delta^{18} \mathrm{O}\right)$ and some of their solutes $\left(\delta^{37} \mathrm{Cl}, \delta^{7} \mathrm{Li}, \delta^{11} \mathrm{~B}\right.$ and ${ }^{87} \mathrm{Sr} /{ }^{86} \mathrm{Sr}$ ); and (iii) $\mathrm{Li}, \mathrm{B}$ and $\mathrm{Sr}$ isotopic compositions of volcanic rock samples surrounding the salar. These results, together with the temperature of the underlying geothermal reservoir estimated from a combination of geothermometers and with PHREEQC modeling of the hydrological system allowed us to identify the main 
82 factor responsible for the abundant precipitation of modern carbonates in Laguna Pastos

83 Grandes.

\section{2. Geological Setting}

85 Laguna Pastos Grandes is located in the southern part of the Bolivian Altiplano, in the 86 South Lipez region. The Altiplano $(3700-4500 \mathrm{~m})$ is a major Plio-Pleistocene continental 87 plateau bounded by the Eastern and Western Cordilleras and dominated by Cenozoic stratovolcanoes and their products (Fig. 1). To the south, rhyolitic ignimbrites and dacites to rhyodacites of the Altiplano-Puna Volcanic Complex (APVC) dominate the South Lipez region, whereas andesites to dacites predominate on the Chilean side (Thorpe et al., 1976). Native sulfur deposits occur on many volcanoes in Chile, and thermal springs are abundant. A thick succession of Cretaceous and Tertiary continental sediments, including evaporite deposits, outcrops in the Bolivian Eastern Cordillera and could be covered by volcanic rocks towards the west in the studied area (Deconinck et al., 2000).

There are more than 200 closed basin lakes in the Bolivian Altiplano and Chilean Western Cordillera (Luddington et al., 1992). Most are saline and encompass a wide range of perennial or ephemeral lakes, locally termed "salars". The two largest salars, Uyuni and Coipasa, are remnants of larger Pleistocene lakes and occupy the lower part of the Altiplano (3650 m altitude), whereas an abundance of smaller evaporitic basins $\left(<400 \mathrm{~km}^{2}\right)$ occur at higher altitudes (4000-4500 m) of the southern Altiplano (Fig. 1). The presence of these southern basins and their morphology primarily result from the cold and dry climate of this region, characterized by mean annual precipitations between 100 and $200 \mathrm{~mm}$, air temperatures varying from $-30{ }^{\circ} \mathrm{C}$ in winter to $25^{\circ} \mathrm{C}$ in summer with daytime fluctuations of up to $40{ }^{\circ} \mathrm{C}$, and annual evaporation of about $1400 \mathrm{~mm}$ (Risacher and Fritz, 1991). Although they belong to relatively similar environments in terms of geology and climate, Andean salars show a wide variety of brine compositions, which can be organized into three major groups: alkaline, sulfate-rich, and calcium-rich brines (Risacher and Fritz, 2009). Different precipitates can be found in association with these brines, the most common being sodium chloride, sodium sulfates to borates, sodium carbonates and calcium sulfates (Risacher and Fritz, 2009). Their formation and evolution are thought to result from the combination of two fundamental factors: the presence of interior drainage basins as a source of solutes and high evaporation rates allowing salt precipitation (Risacher et al., 2003). Inflows to the Andean salars stem from various sources such as permanent and ephemeral streams, shoreline springs, groundwater discharge, and thermal springs. Most of the rainwater falling on the drainage area infiltrates and recharges underlying aquifers. Shoreline spring and hot-spring waters are typically enriched in solutes compared with streams due to the dissolution of ancient and/or present-day evaporitic sediments or through the infiltration and recycling of lake brines. Therefore, the composition of inflow waters feeding Andean salars reflects a mixture from two main sources: (1) dilute waters produced by the alteration of volcanic rocks by meteoric waters and (2) highly concentrated brackish waters derived from brine/salt recycling (Risacher et al., 2003 and references therein). The high rate of evaporation of these inflow waters in ponds and lakes increases the concentration of solutes and leads to the precipitation of a sequence of minerals in the order of their increasing solubility, following diverse evaporative pathways depending on the initial chemistry of inflow waters (Risacher and Fritz, 2009). 
With an area of $\sim 120 \mathrm{~km}^{2}$, Laguna Pastos Grandes is one of the largest salars of the southern Altiplano (Risacher and Eugster, 1979). This salar lies at an altitude of $4450 \mathrm{~m}$ in a $50-\mathrm{km}$-long caldera dated at $2.89 \pm 0.01 \mathrm{Ma}$ by ${ }^{40} \mathrm{Ar} /{ }^{39} \mathrm{Ar}$ of sanidine (Salisbury et al., 2011) and is probably the remnant of a larger lake that once occupied the caldera moat (de Silva and Francis, 1991). The drainage basin $\left(660 \mathrm{~km}^{2}\right)$ is limited to the west by rhyolitic lava ridges up to an elevation of $5800 \mathrm{~m}$, and to the east by rhyolitic ignimbrite ridges up to an elevation of $5000 \mathrm{~m}$ (Fig. 1b). Coalescent alluvial fans with thin pebbly soils and xerophytic vegetation surround the laguna. Laguna Pastos Grandes can be divided into two main domains previously identified by Ballivian and Risacher (1981) and Jones and Renaut (1994): the eastern domain corresponds to a playa environment characterized by gypsum and carbonate muds associated with ulexite $\left(\mathrm{NaCaB}_{5} \mathrm{O}_{6}(\mathrm{OH})_{6}\right)$, and the western domain corresponds to a vast $40-\mathrm{km}^{2}$ palustrine carbonate platform, highly fragmented through cryoturbation exposing underlying recent carbonates (muds to calcarenites). Over these recent carbonate deposits, a few ponds no more than one decimeter deep host pisoliths and carbonate concretions up to $20 \mathrm{~cm}$ thick (Fig. 1c). Hydrothermal spring discharge over this platform produces important modern carbonate deposits (Bougeault et al., 2019).

\section{Materials and Methods}

\subsection{Water, gas and rock sampling}

Nine water samples were collected during two sampling trips in January 2016 and March 2017, dry and wet seasons respectively (Tables 1,2). We thus consider our samples as representative of the two main climatic seasons in terms of rainfall. Seven samples of water were selected from five thermal springs including one on the border of the laguna, two samples from cold streams, and one sample of brine from the southwestern part of the laguna (Fig. 2, Tables 1,2). Two samples of fresh snow and one sample of rainfall were also collected respectively in January 2016 and March 2017 in order to constrain the meteoric sources of water in the area (Table A2).

Water samples were filtered using a $0.1 \mu \mathrm{m}$ sterile acrylic filter (Sartorius Minisart ${ }^{\circledR}$ ) fixed at the end of a $50 \mathrm{~mL}$ syringe. For cation analyses, $\sim 20 \mathrm{ml}$ samples were acidified with 3 drops of $\mathrm{HNO}_{3}(16 \mathrm{~N})$ in the field. The temperature and $\mathrm{pH}$ were measured on site at each collection point. In 2016, in the field, the total alkalinity was determined by $\mathrm{H}_{2} \mathrm{SO}_{4}(1.6 \mathrm{~N})$ titration using a manual titrator and adapted cartridge $\left(\operatorname{Hach}^{\circledR}\right.$; error below $1 \%$, Table 2; Gran, 1952). Samples of $25 \mathrm{ml}$ were titrated and 25 titrations (pH and volume of added titrated acid) were numerically processed using the Gran function (Gran, 1952). The correlation factors obtained by regression on the derivate of the titration curve are better than 0.998 . In 2017, the total alkalinity was determined by end-point titration with $\mathrm{HCl}$ $(1 \mathrm{~N}$ or $0.1 \mathrm{~N})$ with an automatic titrimeter (Metrohm) at the Total laboratory (France, error below 1\%; Rounds and Wilde, 2012). The bicarbonates alkalinity was calculated from the total alkalinity corrected from the contribution of weak acid and $\mathrm{B}(\mathrm{OH})_{4}^{-}$concentration. The $\mathrm{B}(\mathrm{OH})_{4}^{-}$concentration was calculated from the B concentration (obtained with ICPAES) and the $\mathrm{pH}$ of the sampled solution. The weak acid $\left(\mathrm{HCOO}^{-} ; \mathrm{CH}_{3} \mathrm{COO}^{-} ; \mathrm{C}_{2} \mathrm{H}_{5} \mathrm{COO}^{-}\right.$ ; i- $\mathrm{C}_{3} \mathrm{H}_{7} \mathrm{COO}^{-} ; \mathrm{n}^{-} \mathrm{C}_{3} \mathrm{H}_{7} \mathrm{COO}^{-}$) were measured by ionic chromatography (930 Compact IC Flex, Metrohm). Considering the high alkalinities of the samples, the contribution of $\mathrm{OH}^{-}$ remains negligible. In this article, the alkalinity refers to the $\mathrm{HCO}_{3}{ }^{-} / \mathrm{CO}_{3}{ }^{2-}$ alkalinity.

Four thermal springs named La Salsa, La Rumba, El Ojo Verde and El Gigante (Fig. 2) were selected for both water and gas sampling on the carbonate platform based on 
accessibility and high water-gas flux. La Salsa, La Rumba and El Ojo Verde springs contain bubbling sources of gas in water ponds whereas El Gigante is a dry source of gas (a mofet) away from the main water source. Gases were collected in March 2017 in 100- and 250$\mathrm{mL}$ stainless-steel reservoirs and in four $12 \mathrm{~mL}$ Exetainer ${ }^{\circledR}$ vials, all previously evacuated to primary vacuum. To capture bubbling thermal spring gases, an inverted funnel connected to a rubber pipe was submerged in spring water and placed on top of the rising bubbles (Fig. A1). The other end of the pipe was connected through a T-junction to a stainless-steel fitting ending in a septum (for sampling in an Exetainer ${ }^{\circledR}$ ) and a stainlesssteel reservoir (for direct sampling) connected to a GA5000 gas detector (Scientific Instruments). Before collecting the gases accumulated in the funnel, the sampling system was completely flushed by the continuously outgassing bubbles to avoid air contamination $\left(\mathrm{O}_{2}\right.$ level typically below $\left.2.0 \%\right)$.

Five rock samples of volcanic bedrock ( 2 andesites, 2 dacites and 1 ignimbrite of rhyolitic composition) were also collected on the border of the laguna (see location in Fig. 2).

\subsection{Analytical methods - Chemical compositions}

\section{Gas composition}

The gas composition was determined on the four samples collected in Exetainer ${ }^{\circledR}$ vials with a Varian 3800 high-resolution gas chromatograph (GC) equipped with Molsieve and Haesep type chromatographic columns at the IFPEN laboratory (Rueil-Malmaison, France). $\mathrm{H}_{2}$ and $\mathrm{He}$ quantification was performed using a thermal conductivity detector (TCD) with $\mathrm{N}_{2}$ as the carrier gas, whereas $\mathrm{CO}_{2}, \mathrm{~N}_{2}, \mathrm{O}_{2}$ and $\mathrm{CH}_{4}$ were quantified using a TCD with $\mathrm{He}$ as the carrier gas. Relative concentrations were calculated after the chromatographic response had been calibrated in partial pressure for each compound using "Air Liquide TM" and "Saphir". These standards are quality gas mixtures that include $\mathrm{H}_{2}$, $\mathrm{He}, \mathrm{N}_{2}, \mathrm{CO}_{2}, \mathrm{O}_{2}, \mathrm{CH}_{4}, \mathrm{C}_{2} \mathrm{H}_{6}, \mathrm{C}_{3} \mathrm{H}_{8}, \mathrm{n}-\mathrm{C}_{4} \mathrm{H}_{10}$ and i- $\mathrm{C}_{4} \mathrm{H}_{10}$, available in the laboratory at different concentrations bracketing the samples' composition range. Each sample analysis was followed by a blank analysis to ensure the absence of carry over. Results are given with a precision of \pm 5 vol. $\%$ for $\mathrm{O}_{2}, \pm 1.3$ vol. $\%$ for $\mathrm{CO}_{2}, \pm 3$ vol. $\%$ for $\mathrm{N}_{2}$ and \pm 0.1 vol. $\%$ for $\mathrm{CH}_{4}$ based on replicate measurements of gas standards of similar concentrations.

\section{Water composition}

All chemical analyses were carried out in the Total laboratories (Pau, CSTJF, France) using ion chromatography $\left(\mathrm{Cl}, \mathrm{Br}\right.$ and $\left.\mathrm{SO}_{4}\right)$, Inductively Coupled Plasma-Atomic Emission Spectroscopy ( $\mathrm{Li}, \mathrm{B}$ and $\mathrm{Sr}$ ), Inductively Coupled Plasma-Mass Spectrometry (Ca and $\mathrm{Mg}$ ), and Flame Emission Spectrometry ( $\mathrm{Na}, \mathrm{K}, \mathrm{Ca}$ and $\mathrm{SiO}_{2}$ ). Accuracy for major elements was better than $\pm 5 \%$ and verified by repeated measurements of certified standard materials, namely Ion96-3 and LGC6020 (river waters) for cations and anions, and diluted $\mathrm{Li}$ and B ICP-AES standard solutions (Merck). Saline samples were analyzed either after dilution (to minimize matrix effects during measurement) or by adding a standard (to match the matrix of the standard materials). The matrix effects were validated on at least three dilutions $(500,1000,2000)$.

\subsection{Analytical methods - Isotopic compositions}

\section{$\mathrm{CO}_{2}$ gas}

The isotopic composition of the $\mathrm{CO}_{2}$ gas was measured in Exetainer ${ }^{\circledR}$ vials at the IFPEN laboratory using a MAT253 (Finnigan Mat-Thermo Fisher) triple collection mass 
spectrometer coupled to a gas chromatograph, operating with $\mathrm{He}$ as a carrier gas. An internal reference $\mathrm{CO}_{2}$ gas was calibrated with the international gas reference standards RM8562, RM8563 and RM8564 with $\delta^{13} \mathrm{C}_{\mathrm{vPDB}}$ of $-3.76 \pm 0.03 \%$, $-41.56 \pm 0.04 \%$ and $10.45 \pm 0.03 \%$, respectively (Verkouteren and Klinedinst, 2004). All the isotopic compositions given in this study are reported in the usual $\delta$-scale in\%o according to $\delta_{\text {sample }}$ $(\%)=\left\{\left(\mathrm{R}_{\text {sample }} / \mathrm{R}_{\text {standard }}\right)-1\right\} \times 1000$, where $\mathrm{R}$ is the ${ }^{13} \mathrm{C} /{ }^{12} \mathrm{C}$ atomic ratio. The uncertainties on $\delta^{13} \mathrm{C}$ values are better than $\pm 0.4 \%$ o based on the external reproducibility of internal standards.

\section{$\mathbf{N}_{2}$ gas}

The isotopic composition of $\mathrm{N}_{2}$ in gas samples stored in Exetainer ${ }^{\circledR}$ vials or stainless-steel cylinders was measured at the Institut de physique du globe de Paris (IPGP, France). The $\mathrm{N}_{2}$ was purified and isolated from other gases before being transferred to the IRMS dualinlet mass spectrometer Delta + XP (Finnigan Mat-Thermo Fisher) for isotopic analyses. $\mathrm{N}_{2}$ purification was performed using the high vacuum line $\left(\mathrm{P}<10^{-5} \mathrm{mbar}\right)$ described in $\mathrm{Li}$ et al. (2009) (details in Appendix). We obtained a relative uncertainty on the $\delta^{15} \mathrm{~N}$ better than $\pm 0.5 \%$ taking into account the $\mathrm{N}_{2}$ extraction process efficiency and the reproducibility on an internal reference $\mathrm{N}_{2}$ gas, itself calibrated against the air, the international reference standard for $\delta^{15} \mathrm{~N}$ measurements.

\section{Noble gases}

Noble gas isotopic compositions were measured at IPGP using the Helix-SFT (Split Fight Tube, Thermo Instruments ${ }^{\odot}$ ) following the protocol of Moreira et al. (2018) (details in Appendix). For $\mathrm{Ne}$ and Ar, the standard is the atmosphere. The helium standard is a gas collected at the Irene thermal spring (Reunion island) with a ${ }^{3} \mathrm{He} /{ }^{4} \mathrm{He}$ value (R) of $12.56 \pm$ $0.05 \mathrm{R}_{\mathrm{A}}$ (with $\mathrm{R}_{\mathrm{A}}$ the ${ }^{3} \mathrm{He} /{ }^{4} \mathrm{He}$ value of the air $1.4 \times 10^{-6}$ ). For the present study, blank corrections were negligible. Final uncertainties for the isotopic ratios in samples are \pm 0.1 for $\mathrm{R} / \mathrm{Ra}, \pm 0.06$ for ${ }^{20} \mathrm{Ne} /{ }^{22} \mathrm{Ne}, \pm 0.0005$ for ${ }^{21} \mathrm{Ne} /{ }^{22} \mathrm{Ne}, \pm 5$ for ${ }^{40} \mathrm{Ar} /{ }^{36} \mathrm{Ar}$ and correspond to the error propagation of the measured uncertainty, the blank correction, and the correction for mass discrimination.

\section{Water isotopes}

Oxygen and hydrogen isotope measurements were performed at BRGM stable isotope laboratory by equilibrating during one night $1 \mathrm{~mL}$ of water with gas mixtures of $\mathrm{H}_{2}-\mathrm{He}$ and $\mathrm{CO}_{2}-\mathrm{He}$ respectively for $\delta^{2} \mathrm{H}$ and $\delta^{18} \mathrm{O}$, and using a Finnigan MAT 252 mass spectrometer (Assayag et al., 2008). The external precision was $\pm 0.1 \%$ for $\delta^{18} \mathrm{O}$ and \pm $0.8 \%$ for $\delta^{2} \mathrm{H}$ vs. SMOW.

\section{Chlorine}

The chlorine stable isotope compositions were measured at the IPGP on gaseous $\mathrm{CH}_{3} \mathrm{Cl}$ that was prepared and purified with the method described in Godon et al. (2004). The $\delta^{37} \mathrm{Cl}$ measurements were then performed on the dual-inlet IRMS Delta + XP. They are reported in Table A4 with the conventional $\delta^{37} \mathrm{Cl}$ notation in per mil variations relative to Standard Mean Ocean Chlorine (SMOC). In this study, the external reproducibility of the seawater standard was $0 \pm 0.04 \%(1 \mathrm{~s}, \mathrm{n}=18)$ as routinely obtained at IPGP for more than two decades (Godon et al., 2004). Four pore fluid samples were measured twice. The mean difference between duplicates was $0.04 \%$. 


\section{$\delta^{7} \mathbf{L i}$ analysis}

In water samples, lithium isotopic compositions were measured using a Neptune Multi Collector ICP-MS (Thermo Fisher Scientific) at BRGM stable isotope laboratory. ${ }^{7} \mathrm{Li} / 6 \mathrm{Li}$ ratios were normalized to the L-SVEC standard solution (NIST SRM 8545) following the standard-sample bracketing method (Millot et al., 2004). The uncertainties on $\delta^{7} \mathrm{Li}$ values are better than $\pm 0.5 \%$ o $(2 \sigma)$ based on the external reproducibility using internal standards (seawater IRMM BCR-403 and basalt JB-2).

In volcanic rocks, $\mathrm{Li}$ was separated from the matrix by ion-exchange chromatography using the method described in detail by Dellinger et al. (2015). After digestion, a sample aliquot was loaded onto a column filled with AG50-X12 resin and the $\mathrm{Li}$ was eluted in $\mathrm{HCl} 0.2 \mathrm{~N}$. The Li isotopic composition was measured by MC-ICP-MS Neptune (Thermo Scientific, Bremen) at IPGP using an APEX desolvating system and at typical Li concentrations of 20-30 ppb. Each sample was successively measured three times within a standard-sample bracketing (SSB) sequence, yielding five $\delta^{7} \mathrm{Li}$ values from which an average value was derived. Data were corrected for the background intensities recorded before each bracketing standard and each sample. The intensity of the background was no more than $0.5-1 \%$ of the sample intensity. The overall reproducibility and accuracy of the procedure (including solid sample digestion and Li separation) was checked by measurement of the basalt reference material BHVO-2 $\left(\delta^{7} \mathrm{Li}=4.23 \pm 0.83 \%\right.$; Ryu et al., 2014). The external error $(2 \sigma)$ was better than $0.5 \%$. Finally, the concentration of the total procedural blank (acid digestion and column chemistry) was assessed to be less than 0.05 ng, i.e., insignificant compared with the amount of $\mathrm{Li}$ in the samples.

\section{$\delta^{11} B$ analysis}

Boron isotopic compositions of water samples were determined on a Finnigan MAT 261 solid source mass spectrometer in a dynamic mode at BRGM stable isotope laboratory. For these samples, water volumes corresponding to a mass of $10 \mu \mathrm{g}$ of B underwent a two-step chemical purification using Amberlite IRA-743 selective resin according to a method adapted from Gaillardet and Allègre (1995). The uncertainties on $\delta^{11} \mathrm{~B}$ values are better than $\pm 0.3 \% 0(2 \sigma)$ based on the external reproducibility on the internal standard NBS951 $\left(\delta^{11} \mathrm{~B}=4.05398 \pm 0.00105 \%\right)$.

Rock samples were dissolved by alkali fusion and $\mathrm{B}$ was extracted following the procedure of Chetelat et al. (2009) (details in Appendix). Boron isotope ratios were determined by MC-ICP-MS with a direct injection nebulizer (d- DIHEN; Louvat et al., 2014a) at IPGP with a $2 \sigma$ reproducibility between 0.05 and $0.3 \% .{ }^{11} \mathrm{~B} /{ }^{10} \mathrm{~B}$ values are expressed relative to the boric acid standard NBS 951 (NIST).

\section{${ }^{87} \mathrm{Sr} /{ }^{86} \mathrm{Sr}$ measurement}

For water samples, chemical purification of $\operatorname{Sr}(\sim 3 \mu \mathrm{g})$ was performed using an ionexchange column (Sr-Spec) before mass analysis according to a method adapted from Pin and Bassin (1992) with total blank $<1 \mathrm{ng}$ for the entire chemical procedure. After chemical separation, around $150 \mathrm{ng}$ of $\mathrm{Sr}$ were loaded onto a tungsten filament with tantalum activator and analyzed with a Finnigan MAT 262 multi-collector mass spectrometer at BRGM's stable isotope laboratory. The ${ }^{87} \mathrm{Sr} /{ }^{86} \mathrm{Sr}$ values were normalized to the certified value of the NBS987 standard 0.710240 . An average internal precision of $\pm 10 \mathrm{ppm}(2 \mathrm{\sigma m})$ was obtained and the reproducibility of the ${ }^{87} \mathrm{Sr} /{ }^{86} \mathrm{Sr}$ ratio measurements was verified by repeated analysis of the NBS987 standard $\left({ }^{87} \mathrm{Sr} /{ }^{86} \mathrm{Sr}=0.710243 \pm 10,2 \sigma\right)$. 
For volcanic rocks, after total evaporation of $\sim 0.2 \mathrm{~mL}$ of rock sample digestion SPEC (Eichrom) resin chromatography column to separate ca. $200 \mathrm{ng}$ of $\mathrm{Sr}$ (Pin and 318 Bassin, 1992). The Sr isotopic composition was measured by MC-ICP-MS at IPGP. The 319 mass discrimination was corrected using the invariant ratio ${ }^{88} \mathrm{Sr} /{ }^{86} \mathrm{Sr}(0.1194)$. Accuracy and reproducibility were verified by repeated analysis of the NBS standard SRM 987 $\left({ }^{87} \mathrm{Sr} /{ }^{86} \mathrm{Sr}=0.710250 \pm 0.0000025\right)$.

323 The PHREEQC software, version 3 (Parkhurst and Appelo, 2013) was applied to compute aqueous speciation and fluid-mineral equilibria using the "thermoddem v1.10 06jun2017" thermodynamic database (website http://thermoddem.brgm.fr/; Blanc et al., 2012).

\section{Results}

4.1 Gas molecular and noble gases composition

329

330

331

Table 1. Analytical results of the gas sampled in 2017. $\delta^{15} N$ and $\delta^{13} C$ values are averaged from multiple measurements $(n=2-6)$ except for sample PG17_116, which was analyzed only once for $\delta^{15} N$ (details in Table A1). See text for calculations of atmospheric $\mathrm{N}_{2}$ proportion, $\delta^{15} N$ correction from atmospheric contribution and modeling results.

\begin{tabular}{|c|c|c|c|c|}
\hline Sample no. & PG17 100 & PG17 112 & PG17 116 & PG17 117 \\
\hline Sample location & La S̄alsa & La Rümba & El Gigante & El Ojo Verde \\
\hline Latitude $\left({ }^{\circ} \mathrm{S}\right)$ & 21.619349 & 21.638776 & 21.64819 & 21.651306 \\
\hline Longitude $\left({ }^{\circ} \mathrm{W}\right)$ & 67.848462 & 67.852883 & 67.848736 & 67.840695 \\
\hline Temperature $\left({ }^{\circ} \mathrm{C}\right)$ & 43.4 & 44.6 & 41.5 & 36.2 \\
\hline \multicolumn{5}{|c|}{ Major composition (vol.\%) } \\
\hline $\mathrm{CO}_{2}$ & 74.7 & 66.2 & 86.0 & 38.4 \\
\hline $\mathrm{CH}_{4}$ & 0.04 & 0.03 & 0.00 & 0.07 \\
\hline $\mathrm{O}_{2}$ & 3.36 & 2.01 & 1.63 & 4.76 \\
\hline $\mathrm{N}_{2}$ & 21.8 & 32.0 & 12.4 & 56.4 \\
\hline$\% \mathrm{~N}_{2 \mathrm{~atm}}$ & 57.3 & 23.4 & 49.1 & 31.5 \\
\hline \multicolumn{5}{|c|}{ Isotopic composition (\%) } \\
\hline$\delta^{13} \mathrm{C}( \pm 0.1 \%, 2 \sigma)$ & -11.2 & -11.2 & -11.2 & -11.0 \\
\hline$\delta^{15} \mathrm{~N}( \pm 0.5 \%, 2 \sigma)$ & 2.7 & 1.8 & 1.6 & 2.3 \\
\hline$\delta^{15} \mathrm{~N}_{\text {primary }}$ & 6.4 & 2.3 & 3.1 & 3.4 \\
\hline \multicolumn{5}{|c|}{ Noble gases (ppm) } \\
\hline${ }^{4} \mathrm{He}$ & 337 & 517 & 109 & 814 \\
\hline${ }^{20} \mathrm{Ne}$ & 0.56 & 1.50 & 0.43 & 2.03 \\
\hline${ }^{36} \mathrm{Ar}$ & 7.1 & 12.9 & 3.6 & 12.2 \\
\hline${ }^{40} \mathrm{Ar} /{ }^{36} \mathrm{Ar}$ & 298 & 288 & 283 & 288 \\
\hline $\mathrm{R}_{\mathrm{C}} / \mathrm{R}_{\mathrm{A}}$ & 3.68 & 3.84 & 3.81 & 3.86 \\
\hline Mantle $\mathrm{He}(\%)$ & 45.4 & 47.3 & 47.1 & 47.6 \\
\hline $\mathrm{CO}_{2} /{ }^{3} \mathrm{He}_{\text {surface }}$ & $4.35 * 10^{8}$ & $2.42 * 10^{8}$ & $1.51 * 10^{9}$ & $8.85 * 10^{7}$ \\
\hline \multicolumn{5}{|c|}{ Modeling } \\
\hline $\mathrm{CO}_{2} / 3 \mathrm{He}_{\text {before degassing }}$ & $1.2 * 10^{8}$ & $9.6^{*} 10^{8}$ & $2.9 * 10^{9}$ & $4.7 * 10^{8}$ \\
\hline $\mathrm{CO}_{2}$ exsolution $(\%)$ & 36 & 23 & 49 & 17 \\
\hline
\end{tabular}


333 Thermal spring gases are mainly composed of $\mathrm{CO}_{2}$ (38.4 to 86 vol. \%) and $\mathrm{N}_{2}$ (12.4 to 56.4 334 vol. \%) with minor amounts of $\mathrm{O}_{2}$ (1.63 to 4.76 vol. \%) and negligible traces of $\mathrm{CH}_{4}(<$ 3350.07 vol. \%; Table 1). $\mathrm{No}_{2}$ and $\mathrm{H}_{2} \mathrm{~S}$ were detected. If we assume that $\mathrm{O}_{2}$ is derived from 336 atmospheric contamination during sampling or natural diffusion into the thermal spring, 337 we obtain a contribution of associated atmospheric $\mathrm{N}_{2}$ up to $57.3 \%$ of the total $\mathrm{N}_{2}$ (Table 338 1). Abundances of the Atmosphere-Derived Noble Gases (ADNG: ${ }^{20} \mathrm{Ne}$ and ${ }^{36} \mathrm{Ar}$ ) are 339 depleted relative to air and follow the composition expected for an Air Saturated Water 340 (ASW; Fig. 3). In contrast, ${ }^{4} \mathrm{He}$ is found in high proportions, from 109 to $814 \mathrm{ppm}$, with a 341 high ${ }^{3} \mathrm{He} /{ }^{4} \mathrm{He}$ value normalized to air $\left(\mathrm{R}_{\mathrm{C}} / \mathrm{R}_{\mathrm{A}}\right)$ of $3.79 \pm 0.08$ (with $\left({ }^{3} \mathrm{He} /{ }^{4} \mathrm{He}\right)$ air $=1.4 \times 10^{-6}$;

342 Table 1). This value indicates a high mantle contribution (Sano and Marty, 1995, see 343 discussion).

\subsection{Gas $C$ and $N$ isotope compositions}

The $\mathrm{CO}_{2}$ gas sampled from thermal springs shows homogeneous $\delta^{13} \mathrm{C}$ values with an average of $-11.1 \pm 0.1 \%$ (Table $1, \mathrm{~A} 1)$. In contrast, the isotopic composition of $\mathrm{N}_{2}\left(\delta^{15} \mathrm{~N}\right)$ is more variable and ranges between 1.6 and $2.7 \pm 0.5 \%$. Nitrogen isotope measurements of sample PG17_112 were performed on gases sampled in both Exetainers ${ }^{\circledR}$ and stainlesssteel tubes to ensure good reproducibility of the results, regardless of the container used (Table A1). Similar values were obtained with a deviation of $\pm 0.3 \%$. Considering an atmospheric contamination of up to $57.3 \%$ for $\mathrm{N}_{2}$, we can estimate the primary $\delta^{15} \mathrm{~N}$ value by isotopic mass balance as follows:

$\delta^{15} \mathrm{~N}_{\text {measured }}=\delta^{15} \mathrm{~N}_{\text {atm }} * \%$ atm $+\delta^{15} \mathrm{~N}_{\text {primary }} *(1-\%$ atm $)$

With atmospheric contamination $\%$ atm up to 0.57 and $\delta^{15} \mathrm{~N}_{\text {atm }}=0 \%$, a maximum $\delta^{15} \mathrm{~N}_{\text {primary }}$ of $6.4 \%$ is obtained (Table 1). We thus consider the measured values as minimum values.

361 Table 2. Chemical and isotopic compositions of Laguna Pastos Grandes waters. NICB: 362 Normalized Ionic Charge Balance.

\begin{tabular}{|c|c|c|c|c|c|c|c|c|c|}
\hline Sample no. & PG17-117 & PG17-112 & PG17-100 & PG1_1 & MV_1 & PGS_1 & PG17_99 & SP_3 & LS_4 \\
\hline Sampling trip & 2017 & 2017 & 2017 & 2016 & 2016 & 2016 & 2017 & 2016 & 2016 \\
\hline Name & $\begin{array}{r}\text { El Ojo Verde } \\
\text { spring }\end{array}$ & $\begin{array}{r}\text { La Rumba } \\
\text { spring }\end{array}$ & $\begin{array}{r}\text { La Salsa } \\
\text { spring }\end{array}$ & $\begin{array}{r}\text { La Salsa } \\
\text { spring }\end{array}$ & $\begin{array}{r}\text { El Gigante } \\
\text { spring }\end{array}$ & $\begin{array}{r}\text { Piedmont } \\
\text { spring }\end{array}$ & Stream & Stream & $\begin{array}{l}\text { Lake } \\
\text { brine }\end{array}$ \\
\hline Lat. $\left({ }^{\circ} \mathrm{S}\right)$ & 21.651306 & 21.638776 & 21.619349 & 21.61934 & 21.64865 & 21.61996 & 21.60764 & 21.69665 & 21.69552 \\
\hline Lg. $\left({ }^{\circ} \mathrm{W}\right)$ & 67.840695 & 67.852883 & 67.848462 & 67.84842 & 67.84866 & 67.85628 & 67.75753 & 67.8098 & 67.80927 \\
\hline $\mathrm{T}\left({ }^{\circ} \mathrm{C}\right)$ & 36.2 & 44.6 & 43.4 & 42.2 & 45.7 & 32.4 & 17.3 & 16.4 & 24.5 \\
\hline $\mathrm{pH}$ & 6.41 & 5.99 & 6.90 & 6.42 & 6.20 & 6.35 & 9.15 & 7.99 & 7.39 \\
\hline Alkalinity on & n site & & & 10.7 & 8.91 & 4.35 & & 0.78 & \\
\hline \multicolumn{10}{|c|}{ Chemical composition (mM) } \\
\hline $\mathrm{Na}$ & 232 & 137 & 173 & 220 & 251 & 23.7 & 0.57 & 1.17 & 3924 \\
\hline $\mathrm{K}$ & 12.9 & 8.7 & 12.5 & 13.4 & 16.6 & 1.8 & 0.14 & 0.36 & 131 \\
\hline $\mathrm{Ca}$ & 10.9 & 6.5 & 10.1 & 11.4 & 12.8 & 0.7 & 0.17 & 0.37 & 59.7 \\
\hline $\mathrm{Mg}$ & 5.8 & 2.8 & 5.2 & 5.4 & 6.0 & 0.4 & 0.13 & 0.18 & 54.6 \\
\hline Alkalinity & 7.4 & 5.3 & 7.4 & 7.4 & 8.9 & 1.8 & 0.90 & 0.79 & 10.9 \\
\hline $\mathrm{SO}_{4}$ & 2.9 & 2.3 & 2.3 & 2.9 & 4.2 & 0.8 & 0.04 & 0.22 & 39.5 \\
\hline $\mathrm{Cl}$ & 278 & 173 & 197 & 258 & 291 & 25.5 & 0.73 & 1.52 & 4375 \\
\hline $\mathrm{Li}$ & 11.1 & 6.6 & 9.9 & 7.7 & 9.6 & 0.8 & 0.02 & 0.25 & 74.8 \\
\hline $\mathrm{Sr}$ & 0.11 & 0.06 & 0.11 & 0.11 & 0.15 & 0.01 & 0.001 & 0.003 & 1.03 \\
\hline B & 3.6 & 2.2 & 3.3 & 3.2 & 4.7 & 0.5 & 0.04 & 0.08 & 28.6 \\
\hline
\end{tabular}




\begin{tabular}{|c|c|c|c|c|c|c|c|c|c|}
\hline $\mathrm{Br}$ & 0.073 & 0.046 & 0.069 & 0.060 & 0.070 & 0.006 & 0.006 & 0.006 & 0.426 \\
\hline $\mathrm{SiO}_{2} *$ & 116 & 101 & 116 & 155 & 152 & 101 & 36 & 60 & 60 \\
\hline Salinity** & 16.2 & 10.1 & 11.5 & 15.1 & 17.0 & 1.49 & 0.04 & 0.09 & 256 \\
\hline NICB $(\%)$ & -1.3 & -7.5 & 6.9 & 0.7 & 2.2 & -3.1 & -26.4 & 3.0 & -2.9 \\
\hline $\mathrm{pCO}_{2}$ (mbar)*** & 141 & 309 & 60.3 & 110.0 & 389.0 & 61.7 & 0.03 & 0.5 & 10.5 \\
\hline \multicolumn{10}{|c|}{ Isotopic compositions $(\% \mathrm{~m} \pm 2 \mathrm{~s})$} \\
\hline$\delta^{2} \mathrm{H}( \pm 0.8)$ & -92.2 & -96.7 & -93.9 & -93.8 & -92.5 & -104.2 & -99.4 & -104.7 & 7.6 \\
\hline$\delta^{18} \mathrm{O}$ н2О $( \pm 0.1)$ & -11.4 & -12.4 & -11.8 & -11.7 & -11.4 & -14.2 & -13.1 & -13.2 & 3.3 \\
\hline$\delta^{7} \mathrm{Li}$ & $5.2 \pm 0.1$ & $5.6 \pm 0.1$ & $3.8 \pm 0.1$ & $3.6 \pm 0.1$ & $4.0 \pm 0.2$ & $2.6 \pm 0.2$ & $4.0 \pm 0.2$ & $10.9 \pm 0.1$ & $3.9 \pm 0.3$ \\
\hline$\delta^{11} \mathrm{~B}$ & $-4.4 \pm 0.1$ & $-5.0 \pm 0.1$ & $-4.9 \pm 0.2$ & $-4.3 \pm 0.3$ & $-6.7 \pm 0.3$ & $-6.0 \pm 0.3$ & & $0.0 \pm 0.3$ & $-7.2 \pm 0.3$ \\
\hline${ }^{87} \mathrm{Sr} /{ }^{86} \mathrm{Sr}$ & 0.708384 & 0.708412 & 0.708398 & 0.708396 & 0.708402 & 0.708354 & 0.707950 & 0.707646 & 0.708327 \\
\hline $2 \mathrm{~s}_{\mathrm{m}}$ & 0.000005 & 0.000006 & 0.000010 & 0.000007 & 0.000006 & 0.000006 & 0.000010 & 0.000007 & 0.000007 \\
\hline
\end{tabular}

$363 * m g / L ; * * g / L ; * * *$ calculated with PHREEQC based on water chemistry

364

365 Spring waters exhibit a narrow range of $\delta^{18} \mathrm{O}(-14.2$ to $-11.4 \%)$ and $\delta^{2} \mathrm{H}(-104.2$ to $-92.2 \%)$,

366 slightly more enriched in ${ }^{18} \mathrm{O}$ and ${ }^{2} \mathrm{H}$ than streams (with $\delta^{18} \mathrm{O} \sim-13.2 \%$ and $-104.7<\delta^{2} \mathrm{H}$

$367<-99.4 \%$; Fig. 4, Table 2). They are located on the regional Ground and Spring Water Line

368 (LGSWL; $\delta^{2} \mathrm{H}=7.99 \times \delta^{18} \mathrm{O}+0.3 ; \mathrm{n}=44$ ) established by Fritz et al. (1981) and Rissmann

369 et al. (2015) to the right of the Local Meteoric Water Line (LMWL) defined for modern

370 precipitation in the Chilean and Bolivian Altiplano at altitudes of 2800 to $5700 \mathrm{~m}\left(\delta^{2} \mathrm{H}=\right.$

$3718.15 \times \delta^{18} \mathrm{O}+15.3$; Chaffaut et al., 1998). Streams and springs define a trend given by the

372 following equation: $\delta^{2} \mathrm{H}=4.29 \times \delta^{18} \mathrm{O}+43.8\left(\mathrm{R}^{2}=95 \%, \mathrm{n}=8\right.$; Fig. $\left.4 \mathrm{~b}\right)$ with $\delta^{18} \mathrm{O}$ and

$373 \delta^{2} \mathrm{H}$ values more positive than rainfall collected at $4500 \mathrm{~m}$ during the wet season. Two

374 snow samples collected during the dry season show more positive $\delta^{18} \mathrm{O}$ and $\delta^{2} \mathrm{H}$ values

375 than rainfall and fall to the left of the LMWL trend (Table A2). The Piedmont thermal

376 spring, located on the border of the laguna, is shifted from the other springs toward more

377 negative $\delta^{18} \mathrm{O}$ and $\delta^{2} \mathrm{H}$ values. In the southeastern part of Laguna Pastos Grandes, the brine

378 sampled from the lake (LS4 sample) is enriched in both ${ }^{18} \mathrm{O}$ and ${ }^{2} \mathrm{H}$ compared to the inlet

379 waters and has even greater $\delta^{18} \mathrm{O}$ and $\delta^{2} \mathrm{H}$ values than other Andean salars (Fig. 4, Table

380 A2).

381

382

383

384

385

386

387

388

389

390

391

392

393

394

395

396

397

398

399

400

\subsection{Geothermometry}

The thermal waters associated with gases reach the surface at up to $46^{\circ} \mathrm{C}$, which is among the highest temperatures recorded in the Altiplano salars (Risacher and Fritz, 1991; Spiro et al., 1997). Based on the concentrations of some soluble elements ( $\mathrm{Si}, \mathrm{Na}, \mathrm{K}, \mathrm{Ca}, \mathrm{Mg}, \mathrm{Li}$ ) in the thermal springs, we calculated the maximum temperature of the fluids at depth using empirical, semi-empirical and experimental equilibrium relations between water and minerals in the geothermal reservoirs (Sanjuan et al., 2014 and references therein). We used several geothermometers including silica, $\mathrm{Na}-\mathrm{K}-\mathrm{Ca}, \mathrm{Na}-\mathrm{Li}, \mathrm{Li}-\mathrm{Mg}$, Li isotopes, and Na-K (details in Appendix; Table A3). They yield equilibrium temperatures for spring waters reacting with rocks of a deep reservoir that are comprised between $149 \pm 11^{\circ} \mathrm{C}$ and $325 \pm 21{ }^{\circ} \mathrm{C}$. The lowest value, given by the silica geothermometer, is probably underestimated because of silica precipitation during thermal water cooling (Verma and Santoyo, 1997). The highest value, given by $\mathrm{Na} / \mathrm{Li}$ geothermometers, is overestimated because Li concentrations in the fluids are higher than those used for calibrations (Sanjuan et al., 2014). We thus retain a range of temperature between 200 and $250{ }^{\circ} \mathrm{C}$ obtained using $\delta^{7} \mathrm{Li}\left(200 \pm 25^{\circ} \mathrm{C}\right.$; Millot et al., 2010) and $\mathrm{Na} / \mathrm{K}\left(228 \pm 9{ }^{\circ} \mathrm{C}\right.$ and $205 \pm 12{ }^{\circ} \mathrm{C}$; Verma and Santoyo, 1997; Santoyo and Diaz-Gonzalez, 2010) geothermometers, as the maximum temperature encountered by the water through the faults of the Pastos Grandes caldera. 
401

402

403

404

405

406

407

408

409

410

411

412

413

414

415

416

417

418

419

420

421

422

423

424

425

426

\subsection{Chemical composition of the water}

As extensively demonstrated in previous papers (Roche et al., 1991; Moquet et al., 2011), we assumed the atmospheric contribution to groundwater chemistry as negligible in this region and did not correct the data from this contribution. Elemental concentrations reported in this study are represented and interpreted together with those from previous studies of Laguna Pastos Grandes (Ballivian and Risacher, 1981; Hurlbert and Chang, 1984; Risacher and Fritz, 1991; Jones and Renaut, 1994). Spring waters have higher salinity $(\sim 14 \mathrm{~g} / \mathrm{L})$ than streams $(0.09 \mathrm{~g} / \mathrm{L})$ and homogeneous $\delta^{37} \mathrm{Cl}$ values of $0.25 \pm 0.03 \%$ o $(\mathrm{n}=12$; Table A4). The Piedmont spring is the only exception with a relatively low salinity of $1.9 \mathrm{~g} / \mathrm{L}$. The brines from the southeastern part of the laguna are more saline than the water sources (256 g/L; Table 2).

Most of the waters show charge balances better than $\pm 8 \%$ (Table 2 ), which denote a negligible influence of potential organic charges to the ionic balance. Due to higher sensitivity of low concentration samples to analytical errors, one stream sample shows a charge balance of $-26 \%$ corresponding to a low anion excess of $0.41 \mathrm{mM}$.

Sodium and chloride are the dominant ions in spring waters, with average concentrations of 173 and $203 \mathrm{mM}$, respectively. With a Ca:Mg molar ratio ranging from 1.9 to 2.4, spring waters are enriched in Ca relative to $\mathrm{Mg}$. Hydrothermal springs show similar relative ion concentrations suggesting that a common origin and common processes constrained the chemistry of their major elements (Fig. 5a). Their Ca:alkalinity molar ratio is favorable to the precipitation of large amounts of calcite (with a ratio of almost one $\mathrm{Ca}$ for two $\mathrm{C}$ ). Compared with the hydrothermal springs, the Piedmont spring is diluted by surface waters. As for the laguna brine, it presents relative ion concentrations similar to those of the hydrothermal springs but with lower alkalinity (Fig. 5b).

$427 \quad 4.6 \delta^{7} \mathbf{L i}, \delta^{11} \mathrm{~B}$ and ${ }^{87} \mathrm{Sr} /{ }^{86} \mathrm{Sr}$ in waters compared with surrounding rocks

428 Table 3. Chemical and isotopic data available for dacites, andesites and ignimbrites from 429 Laguna Pastos Grandes. Data in italic are from previous studies.

\begin{tabular}{|c|c|c|c|c|c|c|c|c|}
\hline Rock type & $\mathrm{Ca} / \mathrm{Na}$ & $\mathrm{Mg} / \mathrm{Na}$ & $\begin{array}{c}\mathrm{Li}(\mathrm{ppm}) \\
\pm 0.3 \text { 1SD }\end{array}$ & $\delta^{7} \mathrm{Li}(\%)$ & $\begin{array}{c}\text { B (ppm) } \\
\pm 0.31 \mathrm{SD}\end{array}$ & $\delta^{11} \mathrm{~B}(\%)$ & $\begin{array}{c}\mathrm{Sr}(\mathrm{ppm}) \\
\pm 3 \text { 1SD }\end{array}$ & ${ }^{87} \mathrm{Sr} /{ }^{86} \mathrm{Sr}$ \\
\hline Ignimbrite & 0.61 & 0.30 & 66.9 & $-3.33 \pm 0.47$ & 54 & $-7.79 \pm 0.21$ & 330 & 0.725764 \\
\hline Dacite 1 & 0.70 & 0.45 & 147.4 & $-5.82 \pm 0.12$ & 60 & $-14.88 \pm 0.21$ & 351 & 0.707906 \\
\hline Dacite 2 & 0.87 & 0.36 & 80.2 & $-5.43 \pm 0.35$ & 30 & $-13.70 \pm 0.15$ & 464 & 0.706951 \\
\hline Andesite 1 & 1.69 & 1.50 & 279.7 & $-5.11 \pm 0.38$ & 144 & $-13.57 \pm 0.09$ & 690 & 0.705835 \\
\hline Andesite 2 & 2.13 & 1.61 & 147.8 & $-9.22 \pm 0.15$ & 116 & $-13.89 \pm 0.10$ & 706 & 0.706206 \\
\hline \multicolumn{8}{|c|}{ Ignimbrite (Kaiser, 2014) } & 0.708173 \\
\hline \multicolumn{8}{|c|}{ Ignimbrite (Kaiser, 2014) } & 0.708040 \\
\hline \multicolumn{7}{|c|}{ Cenomanian-Turonian carbonates (McArthur et al., 1994) } & \multicolumn{2}{|c|}{$0.707298-0.707428$} \\
\hline \multicolumn{7}{|c|}{ Modern marine evaporites (Pierret et al., 2001) } & & 0.708940 \\
\hline
\end{tabular}

431 Thermal springs show homogeneous ${ }^{87} \mathrm{Sr} /{ }^{86} \mathrm{Sr}$ values slightly more radiogenic than cold 432 streams with average values of $0.70839 \pm 0.00002$ and $0.70780 \pm 0.00021$, respectively. In 
the eastern part of the laguna, the perennial lake has a ${ }^{87} \mathrm{Sr} /{ }^{86} \mathrm{Sr}$ value of 0.70833 , slightly lower than thermal spring water values. As expected, all waters are within the range reported for dacites $(0.70890 \pm 0.00238$; Cortecci et al., 2005) and andesites $(0.70763 \pm 0.00161$; Cortecci et al., 2005) of the Andean Central Volcanic Zone. Our dataset is also compared with andesites, dacites and rhyolitic ignimbrites sampled in the vicinity of Laguna Pastos Grandes (Table 3). Sr isotope ratios of streams are between those of Pastos Grandes ignimbrites and dacites, whereas springs and brines show compositions carbonates, considered as the last open marine period in the central Andes (Deconinck et al., 2000), is much lower than the values of the thermal springs (with ${ }^{87} \mathrm{Sr} /{ }^{86} \mathrm{Sr}=0.7073$ 0.7074; McArthur et al., 1994).

444 Boron and lithium isotopic compositions of Pastos Grandes waters are also clearly different from seawater composition $\left(\delta^{11} \mathrm{~B}=39.6 \%\right.$ and $\delta^{7} \mathrm{Li}=31.0 \%$; Boschetti et al., 2017). $\delta^{11} \mathrm{~B}$ and $\delta^{7} \mathrm{Li}$ values increase between rock and water samples in the following order: volcanic rocks $<$ hydrothermal springs $=$ lake brines $<$ surface runoff. Pastos Grandes' thermal waters and brine present $\delta^{11} \mathrm{~B}$ and $\delta^{7} \mathrm{Li}$ values around $-5.5 \pm 1.1 \%$ and $+4.1 \pm 1.0 \%$, respectively (Fig. 6b). In comparison, one stream displays more positive values for both $\delta^{11} \mathrm{~B}$ and $\delta^{7} \mathrm{Li}$, at 0 and $10.9 \%$, respectively, whereas surrounding volcanic rocks are more negative, with $\delta^{11} \mathrm{~B}$ between -14.9 and $-7.8 \%$ and $\delta^{7} \mathrm{Li}$ between -9.2 and $-3.3 \%$ (Fig. 6b; Table 3). In the study area, volcanic rocks have high $\mathrm{Li}$ and B concentrations (67-280 ppm of $\mathrm{Li}$ and 30-144 ppm of B) and isotopic compositions depleted in ${ }^{7} \mathrm{Li}$ and ${ }^{11} \mathrm{~B}$ compared to the range of values for the Andean volcanic arc: $3-9 \mathrm{ppm}$ of $\mathrm{Li}$ with $-6.4<\delta^{7} \mathrm{Li}<-4.5 \%$ (Chan et al., 2002) and 6-60 ppm of B with $-7<\delta^{11} \mathrm{~B}<+4 \%$ (Rosner et al., 2003). Boron isotopic compositions of Pastos Grandes volcanic rocks are slightly higher than the average continental crust, estimated by Chaussidon and Albarède (1992) between -15 and -10\%.

\subsection{Thermodynamic model}

We compared the average spring water composition and the water chemistry obtained using PHREEQC modeling of volcanic bedrock alteration at $200-250{ }^{\circ} \mathrm{C}$ and $\mathrm{CO}_{2}$ partial pressure varying between 10 and 100 bar (typical of $\mathrm{CO}_{2}$-rich geothermal systems; Lowenstern, 2001). The objective was to determine if the observed concentrations of major cations $(\mathrm{Ca}, \mathrm{Mg}, \mathrm{K}, \mathrm{Na}$ and $\mathrm{Si}$ ) can be reached by dissolution of the volcanic rocks (Table A5, see Appendix for the PHREEQC model) without input of ancient marine sediments. The mineralogy of the volcanic rocks surrounding Laguna Pastos Grandes was modeled with the following suite of minerals from the Thermoddem database (details in Appendix):

- Albite for the source of $\mathrm{Na}$

- Anorthite for $\mathrm{Ca}$

- Pargasite for Mg

- Quartz for Si

- Sanidine for K

In all models tested, the $\mathrm{Si}$ and DIC are higher than in the spring water. $\mathrm{Ca}, \mathrm{Mg}, \mathrm{K}$ and $\mathrm{Na}$ concentrations are best reproduced at $225^{\circ} \mathrm{C}$ and 20 bar of $\mathrm{CO}_{2}$ ( $\mathrm{SI}=1.3$; Fig. A2). To adjust the $\mathrm{Cl}$ concentration in the water, we tried different $\mathrm{Cl}$ sources: pure magmatic $\mathrm{Cl}_{2}(\mathrm{~g})$ or halite. Modeling results were inconclusive with pure magmatic $\mathrm{Cl}_{2}(\mathrm{~g})$ but consistent with halite, suggesting that the salinity of the spring water is provided by halite dissolution. As halite is commonly associated with gypsum in the sedimentary series of the Andean region, we also added anhydrite to the bedrock composition in the model. Despite this, the 
main source of $\mathrm{Ca}$ in the spring waters remains anorthite (Table A5). All minerals were considered in the calculation as infinite reservoirs, except halite, which was fixed by the average $\mathrm{Cl}$ concentration in the spring water $(239 \mathrm{mM})$.

\section{5. Discussion}

483 Laguna Pastos Grandes is a calcic-type salar characterized by Na-Ca-Cl brines that can, 484 according to thermodynamic models, lead to the precipitation of calcite, the first mineral of the evaporation pathway before gypsum and ulexite (Hardie and Eugster, 1970; Risacher and Fritz, 2009). Although 19\% of the salars in Bolivia $(n=6)$ and $24 \%$ in Chile $(n=12$, Table A6) are calcic-type salars, massive calcite precipitation is only observed in Laguna Pastos Grandes. Gypsum, mirabilite $\left(\mathrm{Na}_{2} \mathrm{SO}_{4}\right)$, halite and ulexite dominate the other calcic salars. This means that, in addition to the $\mathrm{Ca}^{2+}$ concentration, at least one parameter varies among the Andean salars and controls the magnitude of calcite precipitation in Laguna Pastos Grandes. The precipitation of carbonate minerals is complicated by biomineralization processes (mediated here by microorganisms; Jones and Renaut, 1994) and reaction kinetics in a near-surface continental environment (with ionic interactions, variable substrates, fluctuating $\mathrm{pH}$, organic molecules and gas-phase interactions; AlonsoZarza and Tanner, 2010). Still, the fundamental reasons why calcite precipitates in significant amounts are that i) $\mathrm{Ca}^{2+}{ }_{(\mathrm{aq})}$ and $\mathrm{CO}_{3}{ }^{2-}{ }_{(\mathrm{aq})}$ are supplied in sufficient concentrations by water inputs and ii) surface processes allow the $\mathrm{pH}$ to increase, thereby dynamically sustaining supersaturation relative to calcite. At Laguna Pastos Grandes, we expect these processes to be related to dissolved $\mathrm{CO}_{2}$ losses, such as degassing, salting-out by evaporation and photosynthesis. Our investigations therefore focused on the origin of $\mathrm{CO}_{2}$ and $\mathrm{Ca}$ enrichment in water inputs.

\subsection{Origin of $\mathrm{CO}_{2}$ and $\mathrm{N}_{2}$ in thermal spring gases}

The thermal springs of Laguna Pastos Grandes discharge not only thermal waters but also gases that are essentially mixtures of $\mathrm{CO}_{2}$ and $\mathrm{N}_{2}$ (Table 1). This is common in the Central Andes (Spiro et al., 1997). Changes in the relative proportions of $\mathrm{CO}_{2}$ and $\mathrm{N}_{2}$ gases between sources in Laguna Pastos Grandes can be partly attributed to changes in the contribution from Air Saturated Waters (ASW) to the hydrothermal system. Indeed, the ${ }^{40} \mathrm{Ar} /{ }^{36} \mathrm{Ar}$ mean value of 289 in thermal springs is close to the air value of 295 (Nier, 1950) and their Atmosphere-Derived Noble Gases abundances (ADNG: ${ }^{20} \mathrm{Ne}$ and ${ }^{36} \mathrm{Ar}$ ) normalized to air indicate that the atmospheric component in thermal springs (including $\mathrm{O}_{2}$ and the atmospheric proportion of $\mathrm{N}_{2}$ ) derives from ASW and not from air-contamination during sampling (Fig. 3).

Despite the ASW component, the mean $\mathrm{R}_{\mathrm{C}} / \mathrm{R}_{\mathrm{A}}$ value of $3.79 \pm 0.08$ (Fig. 3, Table 1) indicates the presence of mantle-derived helium in the ascending hydrothermal gas. Our helium isotope results complement and confirm previous data from the central Andes, including an isolated analysis at Laguna Pastos Grandes (Fig. A3; Hilton et al., 1993; Hoke et al., 1994). Assuming that pure mantle-derived helium is characterized by $R_{C} / R_{A} \sim 8$, we calculated that about $47 \%$ of the helium in Laguna Pastos Grandes is of mantle origin (using the calculations described in Hoke et al., 1994; Table 1), whereas it does not exceed $20 \%$ in other gas sources on the Altiplano. In the Western Cordillera, however, the supply of mantle helium reaches $69 \%$ at the Isluga volcano in Chile, $300 \mathrm{~km}$ north of Laguna Pastos Grandes (Hoke et al., 1994). In addition, the highest temperature of salar springs on 

and at $46^{\circ} \mathrm{C}$ in this study (Table A6). For comparison, the maximum temperature recorded in the Western Cordillera is about $87^{\circ} \mathrm{C}$ (Puchuldiza salar, northern Chile; Risacher et al., 2011). Therefore, the strong mantle influence in Laguna Pastos Grandes is probably due to its proximity to the active volcanic arc of the Western Cordillera (Table A6; Springer and Förster, 1998).

The average $\delta^{13} \mathrm{C}_{\text {value of }} \mathrm{CO}_{2} \sim-11.1 \pm 0.1 \%$ is lower than the typical value of a magmatic mantle-derived $\mathrm{CO}_{2}$ source (between -9 and $-4 \%$; Hoefs, 1980) that would be expected based on $\mathrm{He}$ results. Two hypotheses can be proposed to explain this low value: a contribution of $\mathrm{CO}_{2}$ from sedimentary sources, i.e., organic carbon with $\delta^{13} \mathrm{C}<-20 \%$ (Hoefs, 1980), or carbonate precipitation during fluid ascent. To trace the origin of the $\mathrm{CO}_{2}$, $\delta^{13} \mathrm{C}$ values are generally interpreted in relation to $\mathrm{CO}_{2}{ }^{3} \mathrm{He}$ values (Sano and Marty, 1995). In order to avoid the effects of hydrothermal degassing and liquid-vapor partitioning that could have significantly affected the $\delta^{13} \mathrm{C}$ and $\mathrm{CO}_{2} /{ }^{3} \mathrm{He}$ values of the gas, we determined the $\mathrm{CO}_{2} /{ }^{3} \mathrm{He}$ composition at threshold P-T degassing conditions, using fluid phase equilibrium calculations applied to our system $\left(\mathrm{H}_{2} \mathrm{O}-\mathrm{NaCl}-\mathrm{CO}_{2}-\mathrm{N}_{2}-\mathrm{O}_{2}-\mathrm{He}-\mathrm{Ne}-\mathrm{Ar}\right.$; Rouchon et al., 2016). We assumed that all gaseous $\mathrm{CO}_{2}$ was exsolved at a single supersaturation depth and that there was no carbonate precipitation (which would decrease the $\mathrm{CO}_{2} /{ }^{3} \mathrm{He}$ value). The best results were obtained with an initial meteoric water recharge at high altitude, i.e. $5500 \mathrm{~m}$, and a temperature of $0{ }^{\circ} \mathrm{C}$. This is consistent with the $\delta^{18} \mathrm{O}$ and $\delta^{2} \mathrm{H}$ relationship in the spring waters, which suggests that the geothermal reservoir is fed during the wet season by meteoric water of rainfall isotopic composition (i.e., $\delta^{18} \mathrm{O}$ of $16 \%$ and $\delta^{2} \mathrm{H}$ of $-123 \%$; Fig. 4 and Table A2 for values). Snow deposited during the dry season has different isotopic compositions (minimum $\delta^{18} \mathrm{O}$ of $-6.8 \%$ and $\delta^{2} \mathrm{H}$ of $-30.3 \%$ ). Considering a local geotherm of $45^{\circ} \mathrm{C} / \mathrm{km}$ (Rothstein and Manning, 2003), we calculated between 17 and $49 \% \mathrm{CO}_{2}$ exsolution at a depth of about $25-35 \mathrm{~m}$ (at 2.5-3.5 bar) in the different springs (Table 1). Before degassing, the $\mathrm{CO}_{2} /{ }^{3} \mathrm{He}$ values were higher than those measured at the surface and ranged from $4.7^{*} 10^{8}$ to $2.9^{*} 10^{9}$. These values are in the range or slightly lower than the mantle value of $2 * 10^{9}$ (Marty and Jambon, 1987). The depletion of $\mathrm{CO}_{2}$ relative to ${ }^{3} \mathrm{He}$ in fluids could be consistent with carbonate precipitation during the geothermal fluid ascent. Since carbonates are enriched in ${ }^{13} \mathrm{C}$ relative to original $\mathrm{CO}_{2}$, this would also explain why the remaining $\mathrm{CO}_{2}$ in the gas is depleted in ${ }^{13} \mathrm{C}$ (Ray et al., 2009).

Even so, we cannot completely rule out a minor contribution from thermal or microbial decomposition of organic matter in the underlying but unknown sedimentary rocks, perhaps accompanied to some extent by carbonate dissolution, which could account for the slight shift towards negative $\delta^{13} \mathrm{C}_{\mathrm{CO} 2}$ values relative to the mantle. Likewise, the $\delta^{15} \mathrm{~N}$ values between 2.3 and $6.4 \%$ could reflect a crustal (mean $\delta^{15} \mathrm{~N}=+7 \%$; e.g. Sano et al., 1998) contribution mainly generated by biological or thermal degradation (Boyd, 2001). Although stratovolcanoes and their products dominate the South Lipez landscape of the Altiplano (e.g. de Silva and Francis, 1991), volcanic rocks probably overlained (Ludington et al., 1975) or incorporated (Risacher and Alonso, 2001) Cretaceous and Early Tertiary clastic to evaporitic sediments. Alternatively, as this region is close to the subduction zone of the Nazca plate under the South American plate (the slab being located at a depth of 150-km below the Altiplano; Hoke et al., 1994; Kay and Coira, 2009), organic carbon and nitrogen could be remobilized from the slab by metamorphism (Gorman et al., 2006) and transported through primary melts into crustal intrusions. This hypothesis is supported by 
the high $\mathrm{Li}$ concentrations and light $\delta^{7} \mathrm{Li}$ recorded in volcanic lava flows surrounding Laguna Pastos Grandes (compared with MORB composition representing the upper mantle, $\delta^{7} \mathrm{Li}=3.7 \%$; Misra and Froelich, 2012). It can only be interpreted as the addition of highly-negative $\delta^{7} \mathrm{Li}$ slab-derived fluids to the mantle wedge beneath our study area (Fig. 7; Chan et al., 2002). Boron is also highly concentrated in the volcanic rocks of the area (30-144 ppm) and could come from the same source as Li. However, $\delta^{11} \mathrm{~B}$ values, between -14 and $-8 \%$, are more negative than the lowest value of the slab-derived fluids predicted for the Andes (-2.8\%; Rosner et al., 2003). Boron is more volatile than lithium, and light $\delta^{11} \mathrm{~B}$ values are commonly observed in magmatic rocks (Chaussidon and Albarède, 1992) due to magma degassing effects, which produce ${ }^{11} \mathrm{~B}$ depletion in the residual melt (Jiang and Palmer, 1998).

\subsection{Hydrological history of spring water}

The spring waters in Andean salars have previously been suggested to originate from the recycling of lake brines that continuously infiltrate through their bottom sediments (Risacher and Fritz, 1991; Risacher et al., 2003; Risacher and Fritz, 2009). The origin (and evolution) of the spring waters in Laguna Pastos Grandes can be assessed using their water isotopic composition. Spring waters lie on the local Ground and Spring Water Line (LGSWL) with slightly more positive $\delta^{18} \mathrm{O}$ and $\delta^{2} \mathrm{H}$ values than the local rainfall (Fig. 4), indicating that hydrothermal springs are genetically linked to meteoric waters. The slight enrichment in both ${ }^{18} \mathrm{O}$ and ${ }^{2} \mathrm{H}$ relative to meteoric water may imply either evaporative enrichment prior to infiltration at high altitude (Bershaw et al., 2016) or vapor loss during the ascent of thermal fluids (Cortecci et al., 2005). In comparison, the laguna brine is highly enriched in ${ }^{18} \mathrm{O}$ and ${ }^{2} \mathrm{H}$, ruling out the hypothesis of a significant recharge of the springs by infiltration of the laguna brine. In addition, the $\mathrm{Cl} / \mathrm{Br}$ values of spring waters cannot be explained by a dilution of recycled brines by mixing with groundwater or meteoric water (Fig. 5c). We thus suggest that the solutes in the spring waters more likely derive from the alteration of the bedrock minerals.

\subsection{Volcanic bedrock alteration at high temperature and $\mathrm{pCO}_{2}$}

$\delta^{7} \mathrm{Li}$ and $\mathrm{Na} / \mathrm{K}$ geothermometers applied to spring waters indicate that the meteoric water reached a maximum temperature of $200-250{ }^{\circ} \mathrm{C}$ after infiltration. Due to the high mantlederived $\mathrm{CO}_{2}$ flux delivered in thermal springs, the estimated $\mathrm{pCO}_{2}$ in these waters (between 3 and 389 mbar estimated by PHREEQC; Table 2) spans the range and even exceeds the $\mathrm{pCO}_{2}$ in spring waters of the Altiplano and Western Cordillera at $40-120$ and $10-340$ mbar, respectively (Morteani et al., 2014). This $\mathrm{CO}_{2}$ enrichment can acidify thermal waters to a $\mathrm{pH} \sim 5$ favoring bedrock minerals dissolution and hence thermal waters enrichment in solutes, especially in $\mathrm{Ca}$. To test this hypothesis, we performed a series of PHREEQC simulations to determine the water composition resulting from the alteration of the volcanic bedrock with possible evaporites (halite, gypsum and anhydrite) from a meteoric water at 200,225 and $250{ }^{\circ} \mathrm{C}$ and varying $\mathrm{CO}_{2}$ partial pressures and compared the results to the average spring water composition (Table A5; Fig. A2).

The best results for $\mathrm{Ca}, \mathrm{Mg}$ and $\mathrm{K}$ concentrations in spring waters were obtained by alteration of volcanic minerals at a temperature of $225^{\circ} \mathrm{C}$ and at 20 bar of $\mathrm{CO}_{2}$ (Fig. A2). This amount of $\mathrm{CO}_{2}$ is compatible with the proximity of an ancient pre-eruptive magma reservoir at a depth of $\sim 3 \mathrm{~km}$ as proposed by de Silva and Kay (2018). Under these 
conditions, the main source of $\mathrm{Ca}$ in the water is the dissolution of Ca-rich felspars rather than anhydrite (Table A5). These results are corroborated by Sr isotope data, which suggest that local meteoric waters interact with the host volcanic rocks (dacite, andesite and rhyolitic ignimbrite) rather than with ancient marine carbonates (Fig. 6a). Similarly, the $\delta^{7} \mathrm{Li}$ and $\delta^{11} \mathrm{~B}$ values of the thermal waters and laguna brine are closer to those of the surrounding volcanic rocks than to those of seawater (Fig. $6 \mathrm{~b}$ ). $\delta^{7} \mathrm{Li}$ values measured in waters are on average $8 \%$ higher than those measured in the surrounding rocks. This fractionation corresponds to the equilibrium isotopic fractionation between water and weathered volcanic rocks at high temperature $\left(200 \pm 25^{\circ} \mathrm{C}\right.$; Millot et al., 2010). On the other hand, the average $7 \%$ positive $\delta^{11} \mathrm{~B}$ shift between springs and volcanic rocks can be explained either by adsorption of B on mineral surfaces during the ascent and cooling of hydrothermal fluid to the spring vent (Louvat et al., 2014b) or by the preferential incorporation of light B during carbonate precipitation (Vengosh et al., 1991).

Interestingly, the hydrothermal fluid obtained with these simulations is over-saturated with several carbonate minerals $\left(\mathrm{SI}_{\text {calcite }}=1.23, \mathrm{SI}_{\text {dolomite }}=3.03, \mathrm{SI}_{\text {magnesite }}=2.02\right)$, which supports the hypothesis (based on $\mathrm{CO}_{2}{ }^{\beta} \mathrm{He}$ and $\delta^{13} \mathrm{C}$ data) that carbonate could have precipitated during fluid ascent. The higher Si concentration obtained in our simulations compared with those measured in spring waters together with the low temperature given by the $\mathrm{SiO}_{2}$ geothermometer are also consistent with the precipitation of silica during fluid ascent. Furthermore, the simulations suggest that the salinity of the spring water most likely results from the dissolution of halite deposits. This interpretation is confirmed by the homogeneous $\delta^{37} \mathrm{Cl}$ mean value of the springs at $0.25 \pm 0.03 \%$ o $(\mathrm{n}=12$; Table A4), as expected for halite precipitation in equilibrium with seawater at $25^{\circ} \mathrm{C}\left(\delta^{37} \mathrm{Cl}=0.30 \%\right.$; Eggenkamp et al., 2016). It indicates that over time, multiple cycles of halite precipitation and dissolution without new $\mathrm{Cl}$ inputs to the laguna have homogenized the $\mathrm{Cl}$ isotopic composition of the laguna brine and salts. Therefore, we can assume that $\mathrm{Na}$ and $\mathrm{Cl}$ originate from marine evaporites deposited during the last Cenomanian-Turonian marine period and later remobilized in Cretaceous and Tertiary continental deposits (Deconinck et al., 2000) that could have been either overlain by volcanic rocks or incorporated by volcanic eruptions as suggested by Risacher and Alonso (2001) for gypsum. This is also consistent with equimolar $\mathrm{Cl}$ and $\mathrm{Na}$ concentrations of these waters, typical of halite leaching (Fig. A4).

\subsection{How is Laguna Pastos Grandes unique?}

Ca:alkalinity molar ratios of waters of Laguna Pastos Grandes show that stream waters and mixed sources (Piedmont) are too diluted to contribute significantly to the growth of the carbonate platform. They also show that the laguna brine, which largely derives from spring waters (as suggested by chemical and isotopic data; Figs. 4, 5, 6), has been depleted in carbonate relative to $\mathrm{Ca}$. Therefore, only the thermal springs have the potential to precipitate calcite massively (Fig. 5b). Most of the salars in the Central Andes are fed by thermal spring $(60 \%$ in Bolivia and $78 \%$ in Chile) enriched in solutes compared with streams and regional groundwater (Table A6; Risacher and Fritz, 1991; Risacher et al., 2011). Modern carbonates are, however, absent or minor in these systems and generally precipitated as the first mineral of a more developed evaporitic sequence (Risacher and Fritz, 2009). Laguna Pastos Grandes is unique in this respect, as it hosts a $\sim 40 \mathrm{~km}^{2}$ recentto-modern carbonate platform spatially associated with thermal springs. There is a 
remarkable mantle influence on these springs' temperature and gas composition, as well as 668 on their solute enrichments (the highest of the Central Andes) with an average salinity of $66914 \mathrm{~g} / 1$ (Fig. 7; Table A6). This highlights the high water-rock reactivity of the hydrothermal 670 system of Laguna Pastos Grandes compared to other salars, due to the high flow of $\mathrm{CO}_{2}$ 671 gas from the mantle. Furthermore, the singularity of this laguna is probably related to the 672 mineralogy of the volcanic bedrock since calcic-type salars are limited to the Andean region. For example, Chilean volcanic rocks are known to be enriched in sulfides (Risacher and Alonso, 2001) and could be responsible for the greater abundance of sulfate-type salars (65\%) compared to calcic-type salars.

\section{Conclusion and perspectives}

Bolivian and Chilean salars belong to broadly the same climatic and geological environment (Risacher and Fritz, 2009). Nevertheless, they vary widely in terms of chemistry and salt types mostly as a result of local variations in their fluid sources. In this study, we have shown that the western part of Laguna Pastos Grandes, characterized by abundant carbonate deposits, is mainly fed by thermal spring water, with minor contributions from rainfall and surrounding streams. We demonstrated that these spring waters, over-saturated with calcite, have been enriched in calcium and carbonate alkalinity by the alteration of the volcanic bedrock under high $\mathrm{CO}_{2}$ partial pressure and a temperature of $200-250^{\circ} \mathrm{C}$. The magmatic $\mathrm{CO}_{2}$ and the high heat flow that drive the fluid circulation to the surface are probably due to a shallow pre-eruptive magma chamber as proposed by de Silva et al. (2006) and de Silva and Kay (2018) (i.e. at a typical depth of $\sim 5$ km; Fig. 7). We propose that this doping in magmatic $\mathrm{CO}_{2}$ and the mineralogy of the volcanic bedrock are the reason for the large volumes of carbonates compared to most other modern Andean salars.

This configuration is not exclusive to Laguna Pastos Grandes system and can be found in many continental extensional settings (e.g. in Afar) where we posit, by analogy, that the same mechanisms are involved in the genesis of continental carbonate deposits in volcanic provinces. As identified in this study, the main factors that favor a significant production of carbonates would be a deep source of $\mathrm{CO}_{2}$ and a Ca-rich volcanic basement allowing the following processes to occur:

i. Alteration of a sulfide-poor volcanic bedrock containing Ca-enriched minerals (usually feldspars) at high $\mathrm{pCO}_{2}(20 \mathrm{bar})$ and high temperature $\left(225^{\circ} \mathrm{C}\right)$, leading to cationic enrichment of the waters and yielding calcic type hydrothermal waters.

ii. At the surface, $\mathrm{CO}_{2}$ degassing that leads to a $\mathrm{pH}$ increase and results in carbonate precipitation. $\mathrm{CO}_{2}$ loss may also be driven by photosynthesis.

iii. High evaporation rates, increasing both the solute concentrations above calcite saturation and the associated $\mathrm{CO}_{2}$ salting-out, and resulting in a $\mathrm{pH}$ increase.

Laguna Pastos Grandes is therefore a unique natural laboratory that hosts a great diversity of carbonate facies (including pisoliths, ooids, muds and microbialites; Risacher and Eugster, 1979; Jones and Renaut, 1994; Bougeault et al., 2019), sometimes remarkably similar to ancient equivalents such as Cretaceous Presalt carbonates (Terra et al., 2010; Tosca and Wright, 2015). This laguna could, therefore, be further used to identify the biotic and/or abiotic controls involved in the formation of these carbonate deposits. Indeed, microbial mats and thin, dark, mucilaginous films locally coating the pool floors and pisolith surfaces in Laguna Pastos Grandes (described by Jones and Renaut, 1994 and 
Bougeault et al., 2019) could also influence both the carbonate precipitation and fabrics (Pace et al., 2018; Gomez et al., 2018). Comprehensive geochemical, mineralogical and biodiversity studies are underway to characterize the links between physicochemical parameters, microbial communities and the diversity of carbonate fabrics observed in Laguna Pastos Grandes. These results will provide additional insight into the nature of the biosignatures preserved in microbialites's mineralogy and fabrics and allow us to further interpret the sedimentary record on our planet.

\section{Acknowledgments, Samples, and Data}

We would like to thank Total E\&P Bolivia for field assistance (Serge Nicoletis, Jean-Pierre Meunier, Olivier-Daniel Moreau, Rozmarie Cuellar) and Total Lab (CSTJF, Pau, France; Carole Bortelle, Josiane Sentenac, Valérie Burg) for water analysis; Mathilde Mercuzot (Univ. Burgundy) for field and laboratory assistance (2016); Antoine Cogez for strontium isotopic analysis of volcanic rocks, Pierre Burckel for the chemical composition analysis of volcanic rocks, and BRGM (Catherine Guerrot team) for the chemical and isotopic measurements in water samples (2016). We would also like to thank Dr. Daniel Carrizo for providing the Chilean geological map. Particular thanks go to Magali Bonifacie for constructive discussion on chlorine isotope data. Funding was provided by Total EP R\&D Carbonate Project (E. Poli). Parts of this work were supported by IPGP's multidisciplinary program PARI, and by the Paris-IdF region SESAME Grant no. 12015908. This is IPGP contribution No. 4062.

\section{References}

Alonso-Zarza A. M. and Tanner L. H. (2010) Carbonates in continental settings: Facies, environments, and processes. Dev. Sedim. 61, pp. 378.

Assayag N., Jézéquel D., Ader M., Viollier E., Michard G., Prévot F., and Agrinier P. (2008) Hydrological budget, carbon sources and biogeochemical processes in Lac Pavin (France): constraints from $\delta^{18} \mathrm{O}$ of water and $\delta^{13} \mathrm{C}$ of dissolved inorganic carbon. Appl. Geochem. 23(10), 2800-2816.

Ballivian O. and Risacher F. (1981) Los salares del altiplano boliviano: métodos de estudio y estimación económica. IRD Editions.

Bershaw J., Saylor J.E., Garzione C.N., Leier A. and Sundell K.E. (2016) Stable isotope variations $\left(\delta^{18} \mathrm{O}\right.$ and $\left.\delta^{2} \mathrm{H}\right)$ in modern waters across the Andean Plateau. Geochim. et Cosmochim. Acta 194, 310-324.

Blanc P., Lassin A., Piantone P., Azaroual M., Jacquemet N., Fabbri A., and Gaucher E.C. (2012) Thermoddem: A geochemical database focused on low temperature water/rock interactions and waste materials. Appl. Geochem. 27(10), 2107-2116. Boschetti T., Cortecci G., Barbieri M. and Mussi M. (2007) New and past geochemical data on fresh to brine waters of the Salar de Atacama and Andean Altiplano, northern Chile. Geofluids 7(1), 33-50.

Boschetti T., Toscani L., Iacumin P. and Selmo E. (2017) Oxygen, Hydrogen, Boron and Lithium Isotope Data of a Natural Spring Water with an Extreme Composition: A Fluid from the Dehydrating Slab? Aquat. Geochem. 23(5-6), 299-313. Bougeault C., Vennin E., Durlet C., Muller E., Mercuzot M., Chavez M., Gérard E., Ader M., Virgone A. and Gaucher E. C. (2019). Biotic-Abiotic Influences on Modern Ca-SiRich Hydrothermal Spring Mounds of the Pastos Grandes Volcanic Caldera (Bolivia). Minerals 9(6), 380. Boyd S. R. (2001). Nitrogen in future biosphere studies. Chem. Geol. 176(1-4), 1-30. 
760 Chaffaut I., Coudrain-Ribstein A., Michelot J. L. and Pouyaud B. (1998) Précipitations

761 d'altitude du Nord-Chili, origine des sources de vapeur et données isotopiques. Bull. Inst.

762 Fr. Etudes andines 27, 367-384 (in French).

763 Chan L.H., Edmond J.M., Thompson G. and Gillis K. (1992) Lithium isotopic

764 composition of submarine basalts: implications for the lithium cycle in the oceans. Earth

765 Planet. Sci. Lett. 108, 151-160.

766 Chan L.H. and Kastner, M. (2000) Lithium isotopic composition of pore fluids and

767 sediments in the Costa Rica subduction zone: implications for fluid processes and

768 sediment contribution to arc volcanoes. Earth Planet. Sci. Lett. 183, 275-290.

769 Chan L. H., Leeman W. P. and You C. F. (2002) Lithium isotopic composition of Central

770 American volcanic arc lavas: implications for modification of subarc mantle by slab-

771 derived fluids: correction. Chem. Geol. 182(2-4), 293-300.

772 Chaussidon M. and Albarède F. (1992) Secular boron isotope variations in the continental

773 crust: an ion microprobe study. Earth Planet. Sci. Lett. 108(4), 229-241.

774 Chaussidon M. and Marty B. (1995) Primitive boron isotope composition of the mantle.

775 Science 269, 383-386.

776 Chetelat B., Liu C.-Q., Gaillardet J., Wang Q.L., Zhao Z.Q., Liang C.S., Xiao Y.K.

777 (2009) Boron isotopes geochemistry of the Changjiang basin rivers. Geochim.

778 Cosmochim. Acta 73, 6084-6097.

779 Cortecci G., Boschetti T., Mussi M., Lameli C. H., Mucchino C. and Barbieri M. (2005)

780 New chemical and original isotopic data on waters from El Tatio geothermal field,

781 northern Chile. Geochem. J. 39(6), 547-571.

782 Deconinck J. F., Blanc-Valleron M. M., Rouchy J. M., Camoin G. and Badaut-Trauth D.

783 (2000) Palaeoenvironmental and diagenetic control of the mineralogy of Upper

784 Cretaceous-Lower Tertiary deposits of the Central Palaeo-Andean basin of Bolivia

785 (Potosi area). Sedim. Geol. 132(3-4), 263-278.

786 Dellinger M., Gaillardet J., Bouchez J., Calmels D., Louvat P., Dosseto A., Gorge C.,

787 Alanoca L. and Maurice L. (2015) Riverine Li isotope fractionation in the Amazon River

788 basin controlled by the weathering regimes. Geochim. Cosmochim. Acta 164, 71-93.

789 De Hoog J. C. and Savov I. P. (2018) Boron isotopes as a tracer of subduction zone

790 processes. In Boron Isotopes (eds Springer, Cham), pp. 217-247.

791 de Silva S. L. and Francis P. W. (1991) Volcanoes of the Central Andes. Springer Verlag,

792 Berlin.

793 de Silva S., Zandt G., Trumbull R., Viramonte J. G., Salas G. and Jimenez N. (2006)

794 Large ignimbrite eruptions and volcano-tectonic depressions in the Central Andes: a

795 thermomechanical perspective. In: Trois, C., De Natale, G., Kilburn, C.R.J. (Eds.),

796 Mechanism of Activity and Unrest at Large Calderas, vol. 269. Geol. Soc. London, Spec.

797 Publ., pp. 47-63.

798 de Silva S. and Kay S.M. (2018) Turning up the Heat: High-Flux Magmatism in the

799 Central Andes. Elements 14, 245-250.

800 Durand N., Monger H. C., Canti M. G. and Verrecchia E. P. (2018) Calcium carbonate

801 features. In Interpretation of micromorphological features of soils and regoliths. Elsevier.

802 pp. 205-258.

803 Eggenkamp H. G. M., Bonifacie M., Ader M., and Agrinier P. (2016) Experimental

804 determination of stable chlorine and bromine isotope fractionation during precipitation of

805 salt from a saturated solution. Chem. Geol. 433, 46-56.

806 Fritz P., Suzuki O., Silva C. and Salati E. (1981) Isotope hydrology of groundwaters in

807 the Pampa Del Tamarugal, Chile. J. Hydrol. 53, 161-184. 
Gaillardet J. and Allègre C. J. (1995) Boron isotopic compositions of corals: Seawater or diagenesis record? Earth Planet. Sci. Lett. 136(3-4), 665-676.

810 Godon A., Jendrzejewski N., Eggenkamp H. G., Banks D. A., Ader M., Coleman M. L.

811 and Pineau F. (2004) A cross-calibration of chlorine isotopic measurements and

812 suitability of seawater as the international reference material. Chem. Geol. 207(1-2), 1-

81312.

814 Gomez F. J., Kah L. C., Bartley J. K. and Astini R. A. (2014) Microbialites in a high-

815 altitude Andean lake: multiple controls on carbonate precipitation and lamina accretion.

816 Palaios 29(6), 233-249.

817 Gomez F. J., Mlewski C., Boidi F. J., Farías M. E. and Gérard E. (2018) Calcium

818 carbonate precipitation in diatom-rich microbial mats: the Laguna Negra hypersaline

819 lake, Catamarca, Argentina. J. Sedim. Res. 88(6), 727-742.

820 Gorman P. J., Kerrick D. M. and Connolly J. A. D. (2006) Modeling open system metamorphic decarbonation of subducting slabs. Geochem. Geophy. Geosy. 7(4). Gran, G. (1952). Determination of the equivalence point in potentiometric titrations. Part II. Analyst 77(920), 661-671.

Hardie L. A. and Eugster H. P. (1970) The evolution of closed-basin brines. Min. Soc. Am. Special Paper 3, 273-290.

Hilton D. R., Hammerschmidt K., Teufel S. and Friedrichsen H. (1993) Helium isotope characteristics of Andean geothermal fluids and lavas. Earth Planet. Sci. Lett. 120(3-4), 265-282.

Hoefs J. (1980) Stable isotope geochemistry. Berlin and Heidelberg, Springer Verlag. Hoke L., Hilton D. R., Lamb S. H., Hammerschmidt K. and Friedrichsen H. (1994) ${ }^{3} \mathrm{He}$ evidence for a wide zone of active mantle melting beneath the Central Andes. Earth Planet. Sci. Lett. 128(3-4), 341-355.

Hurlbert S. H. and Chang C. C. (1984) Ancient ice islands in salt lakes of the Central Andes. Science 224(4646), 299-302.

Jiang S. Y. and Palmer M. R. (1998) Boron isotope systematics of tourmaline from granites and pegmatites; a synthesis. Europ. J. Min. 10(6), 1253-1265.

Jones B. and Renaut R. W. (1994) Crystal fabrics and microbiota in large pisoliths from Laguna Pastos Grandes, Bolivia. Sedimentology 41(6), 1171-1202.

Kaiser J. F. (2014) Understanding large resurgent calderas and associated magma systems: the Pastos Grandes Caldera Complex, southwest Bolivia. PhD thesis of Oregon State University.

Kay S. M. and Coira B. L. (2009) Shallowing and steepening subduction zones, continental lithospheric loss, magmatism, and crustal flow under the Central Andean Altiplano-Puna Plateau. Backbone of the Americas: shallow subduction, plateau uplift, and ridge and terrane collision, 204, 229.

Li L., Cartigny P. and Ader M. (2009) Kinetic nitrogen isotope fractionation associated with thermal decomposition of NH3: Experimental results and potential applications to trace the origin of $\mathrm{N}_{2}$ in natural gas and hydrothermal systems. Geochim. Cosmochim. Acta 73(20), 6282-6297.

Louvat P., Moureau J., Paris G., Bouchez J., Noireaux J., Gaillardet J. (2014a) A fully automated direct injection nebulizer (d-DIHEN) for MC-ICP-MS isotope analysis: application to boron isotope ratio measurements. J. Anal. Atom. Spectrom. 29(9), 16981707. 
Louvat P., Gayer E. and Gaillardet J. (2014b) Boron behavior in the rivers of Réunion island, inferred from boron isotope ratios and concentrations of major and trace elements.

856 Proced. Earth Plan. Sc. 10, 231-237.

857 Lowenstern J. B. (2001) Carbon dioxide in magmas and implications for hydrothermal 858 systems. Miner. Deposita 36(6), 490-502.

859 Ludington S., Orris G.J., Cox D.P., Long K.R. and Asher-Bolinden S. (1975) Mineral deposit models. In Geology and Mineral Resources of the Altiplano and the Cordillera Occidental, Bolivia (eds Bleiwas D. J. and Christiansen R. G.). U.S. Geol. Survey Bull. pp. 63-224

Luddington S., Orris G.J., Cox D.P., Long K.R. and Asher-Bolinder S. (1992) Mineral deposit models. In Geology And Mineral Resources Of The Altiplano and Cordillera Occidental, Bolivia (eds by U.S. Geological Survey and Servicio Geolbgico de Bolivia). Bull. US geol. Surv. 1975, pp. 63-89.

Marschall H. R. (2018) Boron isotopes in the ocean floor realm and the mantle. In Boron Isotopes (eds Springer, Cham), pp. 189-215.

Marty B. and Jambon A. (1987) ${ }^{3} \mathrm{He}$ in volatile fluxes from the solid Earth: Implications for carbon geodynamics. Earth Plan. Sci. Lett. 83, 16-26.

McArthur J. M., Kennedy W. J., Chen M., Thirlwall M. F. and Gale A. S. (1994)

Strontium isotope stratigraphy for Late Cretaceous time: direct numerical calibration of the $\mathrm{Sr}$ isotope curve based on the US Western Interior. Palaeogeo. Palaeoclim.

Palaeoeco. 108(1-2), 95-119.

Millot R., Guerrot C. and Vigier N. (2004) Accurate and high-precision measurement of lithium isotopes in two reference materials by MC-ICP-MS. Geostand. Geoanal. Res. 28(1), 153-159.

Millot R., Scaillet B. and Sanjuan B. (2010) Lithium isotopes in island arc geothermal systems: Guadeloupe, Martinique (French West Indies) and experimental approach. Geochim. Cosmochim. Acta 74, 1852-1871.

Misra S. and Froelich P. N. (2012) Lithium isotope history of Cenozoic seawater: changes in silicate weathering and reverse weathering. Science 335(6070), 818-823. Moquet J. S., Crave A., Viers J., Seyler P., Armijos E., Bourrel L., Chavarri E.N, Lagane C., Laraque A., Lavado Casimiro W.S., Pombosa R., Noriega L., Vera A. and Guyot J.L. (2011) Chemical weathering and atmospheric/soil $\mathrm{CO}_{2}$ uptake in the Andean and Foreland Amazon basins. Chem. Geol. 287(1-2), 1-26. Moreira M., Rouchon V., Muller E. and Noirez S. (2018) The xenon isotopic signature of the mantle beneath Massif Central. Geochem. Perspect. Lett. 6, 28-32. Moriguti T. and Nakamura E. (1998) Across-arc variation of Li isotopes in lavas and implications for crust/mantle recycling at subduction zones. Earth Planet. Sci. Lett. 163(1-4), 167-174.

Morteani G., Möller P., Dulski P. and Preinfalk C. (2014) Major, trace element and stable isotope composition of water and muds precipitated from the hot springs of Bolivia: Are the waters of the spring's potential ore forming fluids? Chemie der Erde-Geochemistry 74(1), 49-62.

Nier A. O. (1950) A redetermination of the relative abundances of the isotopes of carbon, nitrogen, oxygen, argon and potassium. Phys. Rev. 77(6), 789-793.

Ozima M. and Podosek F. A. (2002) Noble Gas Geochemistry. Cambridge University Press.

901 Bundeleva I., Patrier P., Galaup S., Yokoyama Y., Franceschi M., Virgone A. and 
Visscher P.T. (2018) Formation of stromatolite lamina at the interface of oxygenicanoxygenic photosynthesis. Geobiology 16(4), 378-398.

904 Parkhurst D.L. and Appelo C.A.J. (2013) Description of input and examples for

905 PHREEQC version 3 - a computer program for speciation, batch-reaction, one-

906 dimensional transport, and inverse geochemical calculations. U.S. geological survey

907 techniques and methods, book 6, chap. A43, pp 497.

908 Pierret M. C., Clauer N., Bosch D., Blanc G. and France-Lanord C. (2001). Chemical and

909 isotopic $\left({ }^{87} \mathrm{Sr} /{ }^{86} \mathrm{Sr}, \delta^{18} \mathrm{O}, \delta \mathrm{D}\right)$ constraints to the formation processes of Red-Sea brines.

910 Geochim. Cosmochim. Acta 65(8), 1259-1275.

911 Pin C. and Bassin C. (1992) Evaluation of a strontium-specific extraction

912 chromatographic method for isotopic analysis in geological materials. Analytica Chimica

913 Acta 269(2), 249-255.

914 Pineau F. and Javoy M. (1983) Carbon isotopes and concentrations in mid-Atlantic ridge

915 basalts. Earth Planet. Sci. Lett. 29, 413-421.

916 Ray M.C., Hilton D.R., Muñoz J., Fischer T.P. and Shaw A.M. (2009) The effects of

917 volatile recycling, degassing and crustal contamination on the helium and carbon

918 geochemistry of hydrothermal fluids from the Southern Volcanic Zone of Chile. Chem.

919 Geol. 266(1-2), 38-49.

920 Risacher F. and Eugster H. P. (1979) Holocene pisoliths and encrustations associated

921 with spring-fed surface pools, Pastos Grandes, Bolivia. Sedimentology 26(2), 253-270.

922 Risacher F. and Fritz B. (1991) Geochemistry of Bolivian salars, Lipez, southern

923 Altiplano: origin of solutes and brine evolution. Geochim. Cosmochim. Acta 55(3), 687-

924705.

925 Risacher F., and Alonso H. (2001) Geochemistry of ash leachates from the 1993 Lascar

926 eruption, northern Chile. Implication for recycling of ancient evaporites. J. volcano.

927 geoth. Res. 109(4), 319-337.

928 Risacher F. and Fritz B. (2009) Origin of salts and brine evolution of Bolivian and

929 Chilean salars. Aquat. Geochem. 15(1-2), 123-157.

930 Risacher F., Alonso H. and Salazar C. (2003) The origin of brines and salts in Chilean

931 salars: a hydrochemical review. Earth-Sci. Rev. 63(3-4), 249-293.

932 Risacher F., Fritz B. and Hauser A. (2011) Origin of components in Chilean thermal

933 waters. J. S. Am. Earth Sci. 31(1), 153-170.

934 Rissmann C., Leybourne M., Benn C. and Christenson B. (2015) The origin of solutes

935 within the groundwaters of a high Andean aquifer. Chem. Geol. 396, 164-181.

936 Roche M.A., Fernandez Jauregui C., Aliaga A., Bourges J., Cortes J., Guyot J.L., Pena J.

937 and

938 Rosner M., Erzinger J., Franz G. and Trumbull R.B. (2003) Slab- derived boron isotope

939 signatures in arc volcanic rocks from the Central Andes and evidence for boron isotope

940 fractionation during progressive slab dehydration. Geochem. Geophy. Geosy. 4, 1-25.

941 Rothstein D.A. and Manning C.E. (2003) Geothermal gradients in continental magmatic

942 arcs: Constraints from the eastern Peninsular Ranges batholith, Baja California, México.

943 In Tectonic evolution of northwestern México and the southwestern USA: Boulder,

944 Colorado (eds. Johnson S.E. et al.) Geological Society of America Special Paper 374, pp.

$945 \quad 337-354$.

946 Rouchon V., Courtial X., Durand I., Garcia B., Creon L. and Mougin P. (2016) A Fluid

947 Phase 

- Application to $\mathrm{CO}_{2} / \mathrm{He}$ Fractionation in Continental Mantle Degassing. Goldschmidt

951 Rounds S. A., and Wilde F. D. (2012) Chapter A6. Section 6.6. Alkalinity and acid 952 neutralizing capacity. In US Geological Survey TWRI book 09.

953 Ryu J. S., Vigier N., Lee S. W., Lee K. S. and Chadwick O. A. (2014) Variation of

954 lithium isotope geochemistry during basalt weathering and secondary mineral transformations in Hawaii. Geochim. Cosmochim. Acta 145, 103-115. Salisbury M. J., Jicha B. R., de Silva S. L., Singer B. S., Jiménez N. C., and Ort M. H. (2011) ${ }^{40} \mathrm{Ar} /{ }^{39} \mathrm{Ar}$ chronostratigraphy of Altiplano-Puna volcanic complex ignimbrites reveals the development of a major magmatic province. Bulletin, 123(5-6), 821-840. Sano Y. and Marty B. (1995) Origin of carbon in fumarolic gas from island arcs. Chem. Geol. 119(1-4), 265-274.

Sano Y., Takahata N., Nishio Y. and Marty B. (1998) Nitrogen recycling in subduction zones. Geophy. Res. Lett. 25, 2289-2292.

Santoyo E., and Díaz-González L. (2010) A new improved proposal of the $\mathrm{Na} / \mathrm{K}$ geothermometer to estimate deep equilibrium temperatures and their uncertainties in geothermal systems. Proceedings World Geothermal Congress, Bali, Indonesia. Sanjuan B., Millot R., Ásmundsson R., Brach M. and Giroud N. (2014) Use of two new $\mathrm{Na} / \mathrm{Li}$ geothermometric relationships for geothermal fluids in volcanic environments. Chem. Geol. 389, 60-81.

Spiro B., Hoke L. and Chenery C. (1997) Carbon-isotope characteristics of $\mathrm{CO}_{2}$ and $\mathrm{CH}_{4}$ in geothermal springs from the Central Andes. Internat. Geol. Rev. 39(10), 938-947. Springer M., and Förster, A. (1998). Heat-flow density across the central Andean subduction zone. Tectonophysics 291, 123-139.

Teboul P. A., Durlet C., Gaucher E. C., Virgone A., Girard J. P., Curie J., ... and Camoin G. F. (2016) Origins of elements building travertine and tufa: New perspectives provided by isotopic and geochemical tracers. Sedim. Geol. 334, 97-114.

Teboul P. A. (2017) Diagenesis of lower Cretaceous presalt continental carbonates from the West African margin: simulations and analogues (Doctoral dissertation, AixMarseille).

Terra G.J.S., Spadini A.R., França A.B., Sombra C.L., Zambonato E.E., da Silva Juschaks L.C., Arienti L.M., Erthal M.M., Blauth M., Franco M.P., Matsuda N.S., da Silva N.G.C., Moretti Junior P.A., D'Avila R.S.F., de Souza R.S., Tonietto S.N., Couto dos Anjos S.M., Campinho V.S. and Winter W.R. (2010) Classificação de rochas carbonáticas aplicável às bacias sedimentares brasileiras. Bulletin Geoscience Petrobras, Rio de Janeiro 18 (1), 9-29

Thorpe R. S., Potts P. J., and Francis P. W. (1976) Rare earth data and petrogenesis of andesite from the North Chilean Andes. Contrib. Mineral. Petr. 54(1), 65-78. Tosca N.J., Wright V.P. (2015) Diagenetic pathways linked to labile Mg-clays in lacustrine carbonate reservoirs: a model for the origin of secondary porosity in the Cretaceous Pre-salt Barra Velha Formation, Offshore Brazil, 435. Geological Society of London, Special Publication. SP435-1.

Vengosh A., Kolodny Y., Starinsky A., Chivas A. R. and McCulloch M. T. (1991) Coprecipitation and isotopic fractionation of boron in modern biogenic carbonates. Geochim. Cosmochim. Acta 55(10), 2901-2910. 
994 Verkouteren R. M. and Klinedinst D. B. (2004) Value Assignment and Uncertainty 995 Estimation of Selected Light Stable Isotope Reference Materials: RMs 8543-8545, RMs 996 8562-8564, and RM 8566. NIST Special Publication 260 (149), 59.

997 Verma S. P. and Santoyo E. (1997) New improved equations for $\mathrm{Na} / \mathrm{K}, \mathrm{Na} / \mathrm{Li}$ and $\mathrm{SiO}_{2}$ 998 geothermometers by outlier detection and rejection. J. Volcanol. Geoth. Res. 79(1-2), 999923.

1000 Verrecchia E.P. (2007) Lacustrine and palustrine geochemical sediments - Chapter 9. In: 1001 Terrestrial geochemical sediments and geomorphology (Eds. D.J. Nash and S.J.

1002 McLaren), Blackwell, London, Oxford, pp. 298-329.

1003 Zamanian K., Pustovoytov K. and Kuzyakov Y. (2016). Pedogenic carbonates: Forms 1004 and formation processes. Earth-Sci. Rev. 157, 1-17. 
1005

1006

1007

1008

1009

1010

1011

1012

1013

1014

1015

1016

1017

1018

1019

1020

1021

1022

1023

1024

1025

1026

1027

1028

1029

1030

1031

1032

1033

1034

1035

1036

1037

1038

1039

1040

1041

1042

1043

1044

1045

1046

1047

1048

1049

1050

1051

1052

\section{Figure Captions}

Fig. 1: a. Topographic map of the Central Andes showing the location of Laguna Pastos Grandes among the main Chilean and Bolivian salars (in white); b. Zoom on the geological context of Laguna Pastos Grandes (modified from Bougeault et al., 2019); satellite image provided by Zoom Earth website, (C) 2018 Microsoft Corporation Earthstar Geographics SIO; c. View of the carbonate platform with partially submerged calcitic pisoliths.

Fig. 2: Location of water and gas sampling in streams (blue stars), thermal springs (red stars) and brine in one of the sustainable lakes (yellow star) in Laguna Pastos Grandes (Bolivia). The location of the volcanic rock samples is also indicated by black dots. The four thermal springs (images 1-4) flow up through the recent carbonate platform developing to the west of the laguna. The arrows indicate gas bubbling in the water basins, except for "El Gigante" where gas and water have separate vents. Ign.: Ignimbrite; Dac.: Dacite; And.: Andesite.

Fig. 3: Relative abundance of air-normalized isotopic composition of noble gas $\left({ }^{4} \mathrm{He},{ }^{20} \mathrm{Ne}\right.$, ${ }^{36} \mathrm{Ar},{ }^{40} \mathrm{Ar} /{ }^{36} \mathrm{Ar}$ and $\left.{ }^{3} \mathrm{He} /{ }^{4} \mathrm{He}\right)$ in thermal springs El Ojo Verde, La Rumba, La Salsa and El Gigante. The normalization values used as references are 295.5 for ${ }^{40} \mathrm{Ar} /{ }^{36} \mathrm{Ar}$ ratio (Nier, 1950) and $1.39 \times 10^{-6}$ for ${ }^{3} \mathrm{He} /{ }^{4} \mathrm{He}$ ratio (Ozima and Podosek, 2002). Helium isotope ratios are corrected for the effects of ASW (Air saturated Water) contamination in hydrothermal system and are equivalent to $\mathrm{Rc} / \mathrm{Ra}$.

Fig. 4: Plot of $\delta^{18} \mathrm{O}$ versus $\delta^{2} \mathrm{H}$ for Pastos Grandes waters. Plot $\mathrm{b}$ is focused on thermal springs (in red) and cold streams (in blue) compared to a rain sample (in white) collected at the same altitude during the wet season in March 2017. Two snow samples (grey) were also collected during the dry season in January 2016. Rainfall and snow data are presented in Table A2. The composition of the lake brine (in yellow) of Pastos Grandes is compared to other Andean salars (in black, based on this study and Boschetti et al., 2007; Table A2). The Local Meteoric Water Line (LMWL; Chaffaut et al., 1998) and the Local Ground- and Spring-Water Line (LGSWL; Rissmann et al., 2015) for the South-Central Andes are also indicated.

Fig. 5: Chemical composition of Laguna Pastos Grandes water sources (thermal springs in red/orange and streams in blue) and lake brine (in yellow). a. Schoeller diagram showing relative concentrations in solutes; b. Plot of Ca versus Alkalinity (mM); c. Plot of $\mathrm{Cl}$ concentration versus $\mathrm{Cl} / \mathrm{Br}$. Data from this study are presented as dots and previous data as squares (Ballivian and Risacher, 1981; Hurlbert and Chang, 1984; Risacher and Fritz, 1991; Jones and Renaut, 1994).

Fig. 6: Sr, Li and B isotopic compositions of Laguna Pastos Grandes water sources (thermal springs in red and streams in blue) and lake brine (in yellow) compared with andesite, dacite (this study), and rhyolitic ignimbrite (this study and Kaiser, 2014) from the Pastos Grandes caldera. a. ${ }^{87} \mathrm{Sr} /{ }^{86} \mathrm{Sr}$ vs $\mathrm{Sr}$ concentration $(\mathrm{mg} / \mathrm{l})$ data compared to CenomanianTuronian marine carbonates (McArthur et al., 1994) representing the last marine sedimentary sequence in the Central Andes region and modern marine evaporites (Pierret et al., 2001). Mean values of dacite (D) and andesite (A) from the Andean Central Volcanic Zone (CVZ) are also given for comparison (Cortecci et al., 2005); b. $\delta^{11} \mathrm{~B}$ vs $\delta^{7} \mathrm{Li}$ data 
1053 compared to modern seawater (Boschetti et al., 2017) and rocks from the Andean volcanic 1054 arc (Chan et al., 2002; Rosner et al., 2003).

1055

1056

1057

1058

1059

1060

1061

1062

1063

1064

1065

1066
Fig. 7: Conceptual model of modern carbonate precipitation in relation to water and gas sources in Laguna Pastos Grandes. Violet-blue arrows refer to hydrothermal circulations. See the conclusion for more details. Boron isotope data are from De Hoog and Savov (2018) for the Altered Oceanic Crust (AOC) and marine sediments and Marschall (2018) for the mantle. Lithium isotope data are from Chan and Kastner (2000) for subducted sediments, Moriguti and Nakamura (1998) and Chan et al. (1992) for AOC and Misra and Froelich (2012) for the mantle. Nitrogen isotope data are from Sano et al. (1998) for the crust. Carbon isotope data are from Hoefs (1980) for sedimentary organic carbon and Pineau and Javoy (1983) for mantle-derived signature. Rc/Ra data are from Hoke et al (1994). Other data are from this study. 
1067 Figure 1
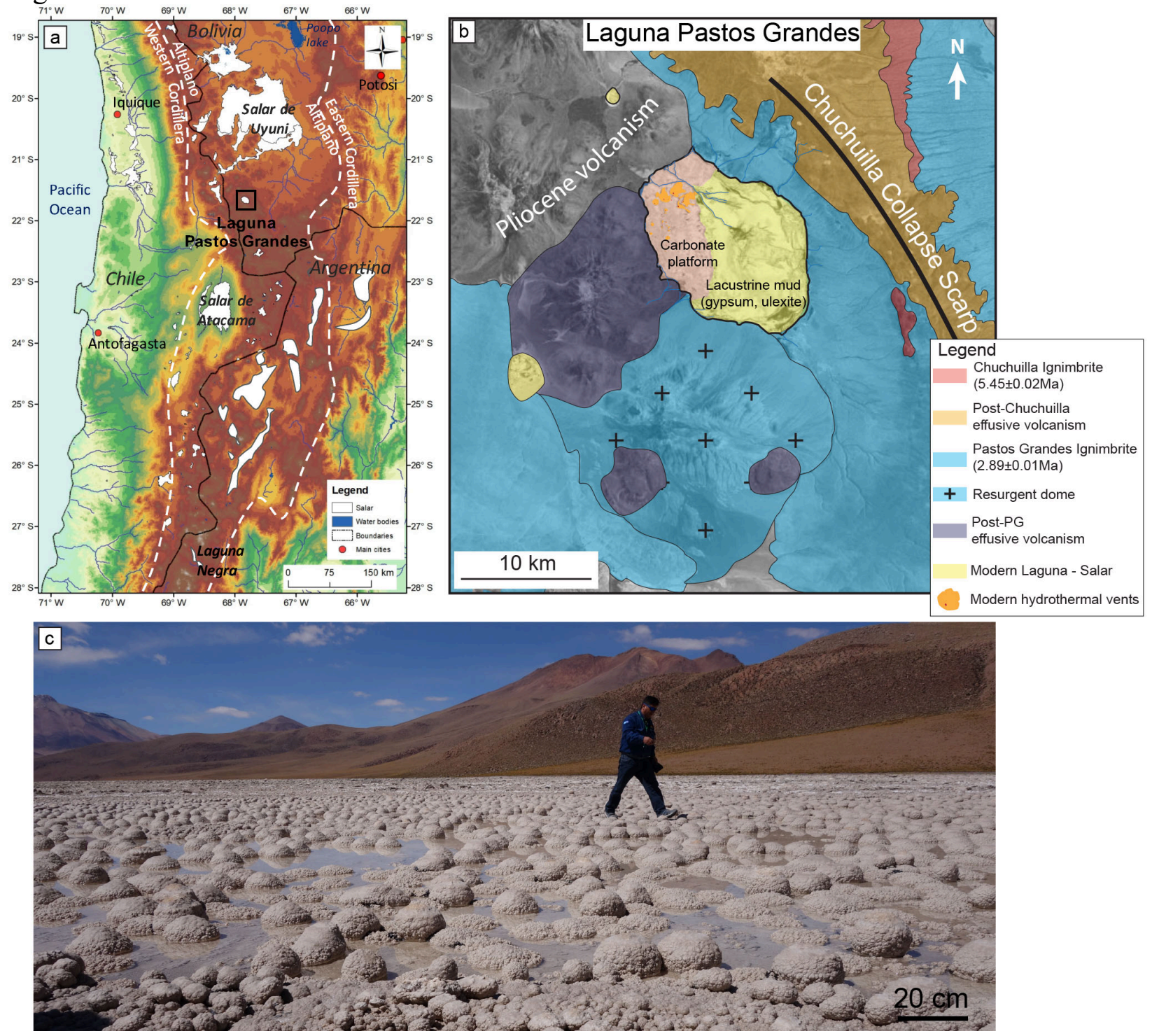

1068 
1070 Figure 2

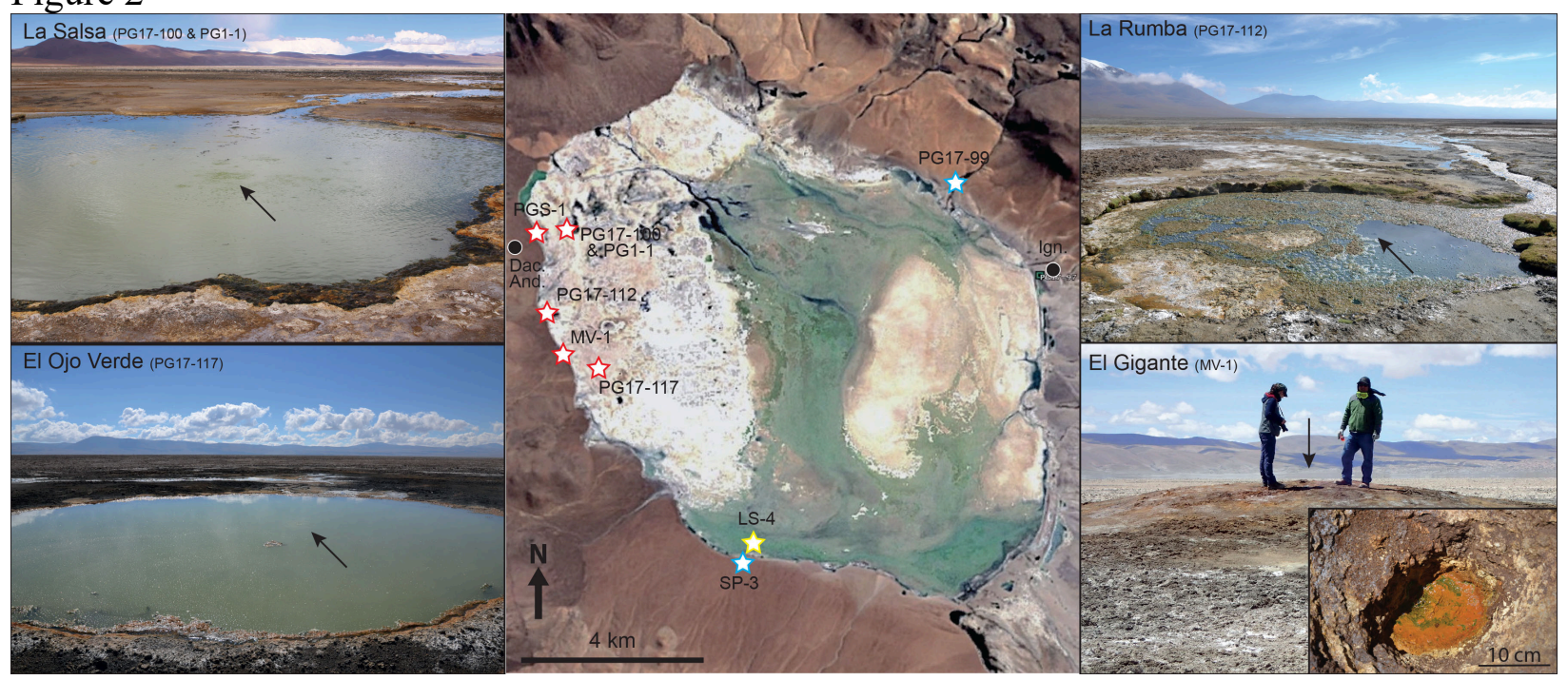

1071

1072 
1073 Figure 3

1074

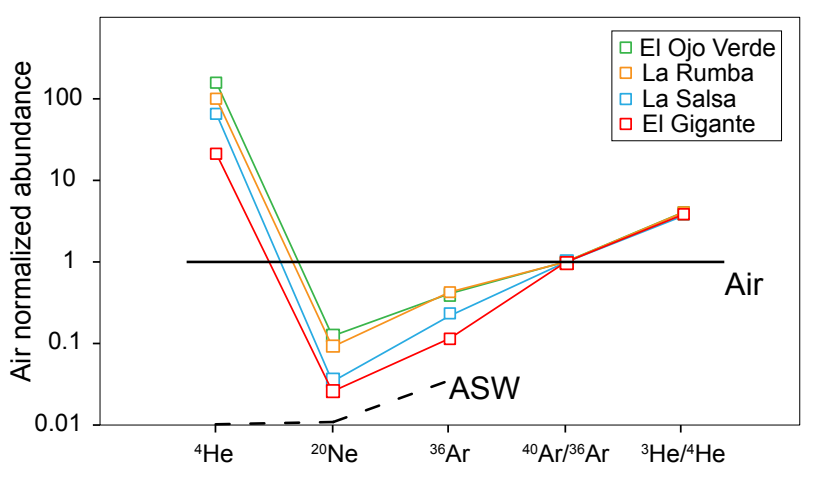

1075 
1076 Figure 4

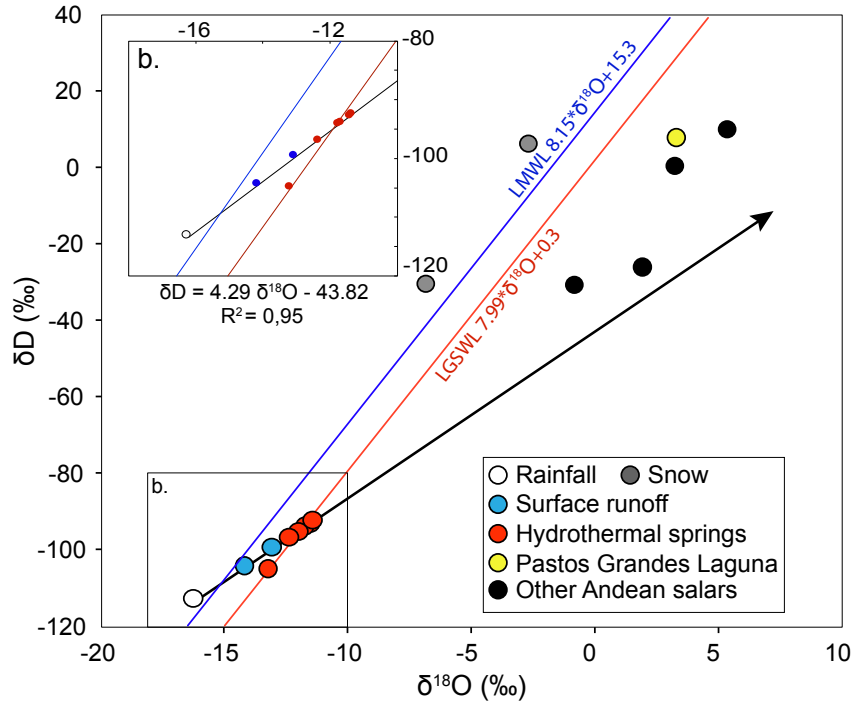

1077

1078 
1079 Figure 5
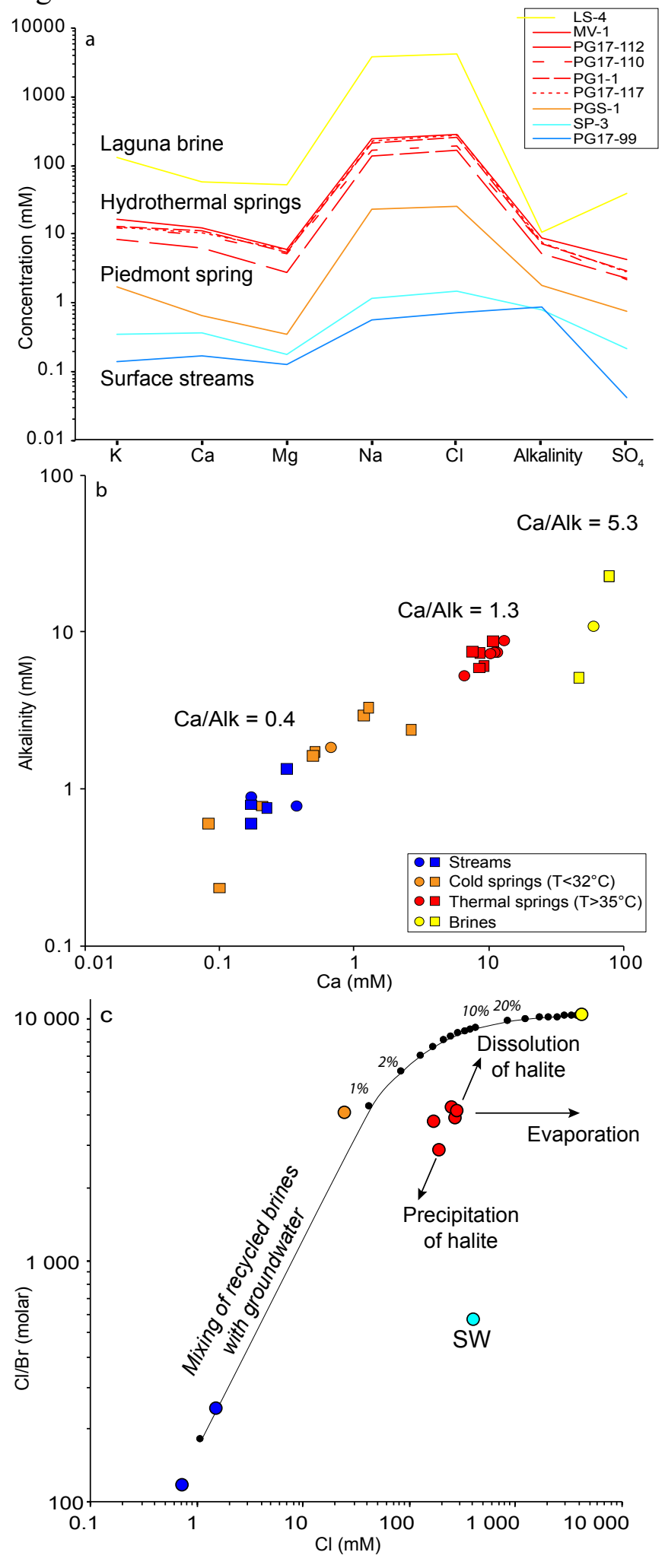

1080

1081 
1082 Figure 6

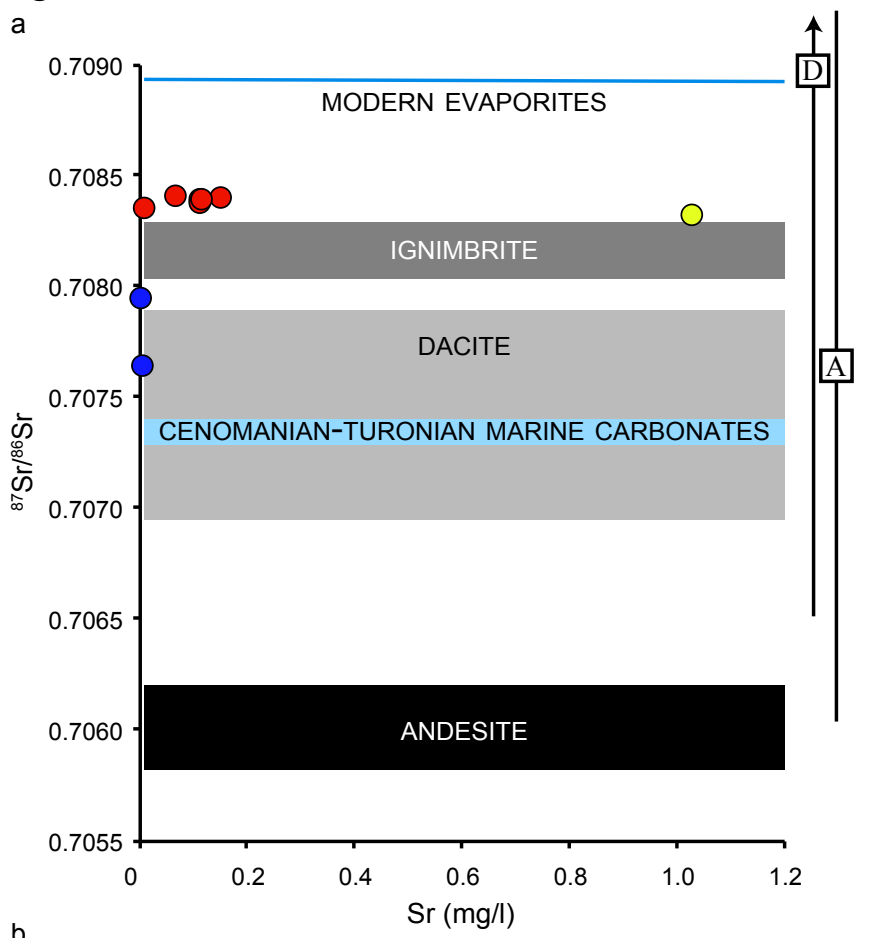

b

1083

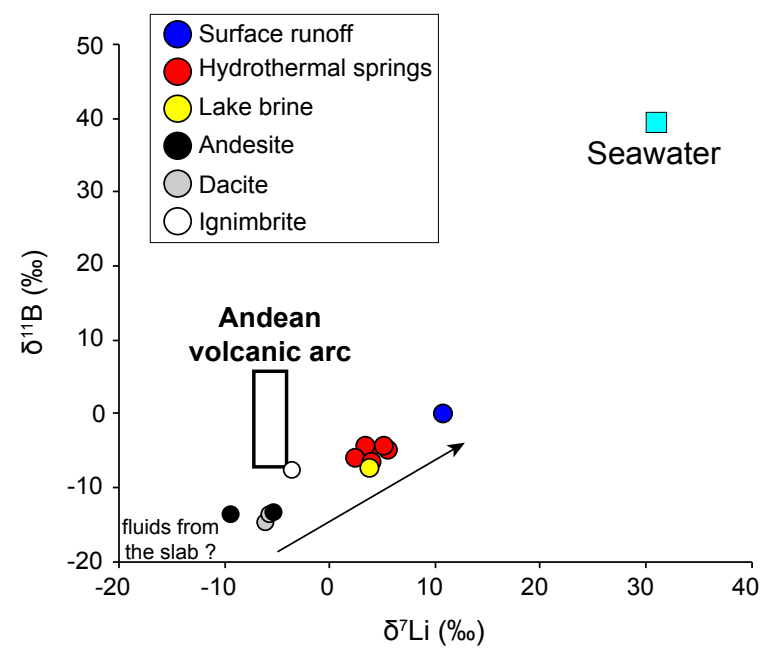

1084 


\section{Figure 7}

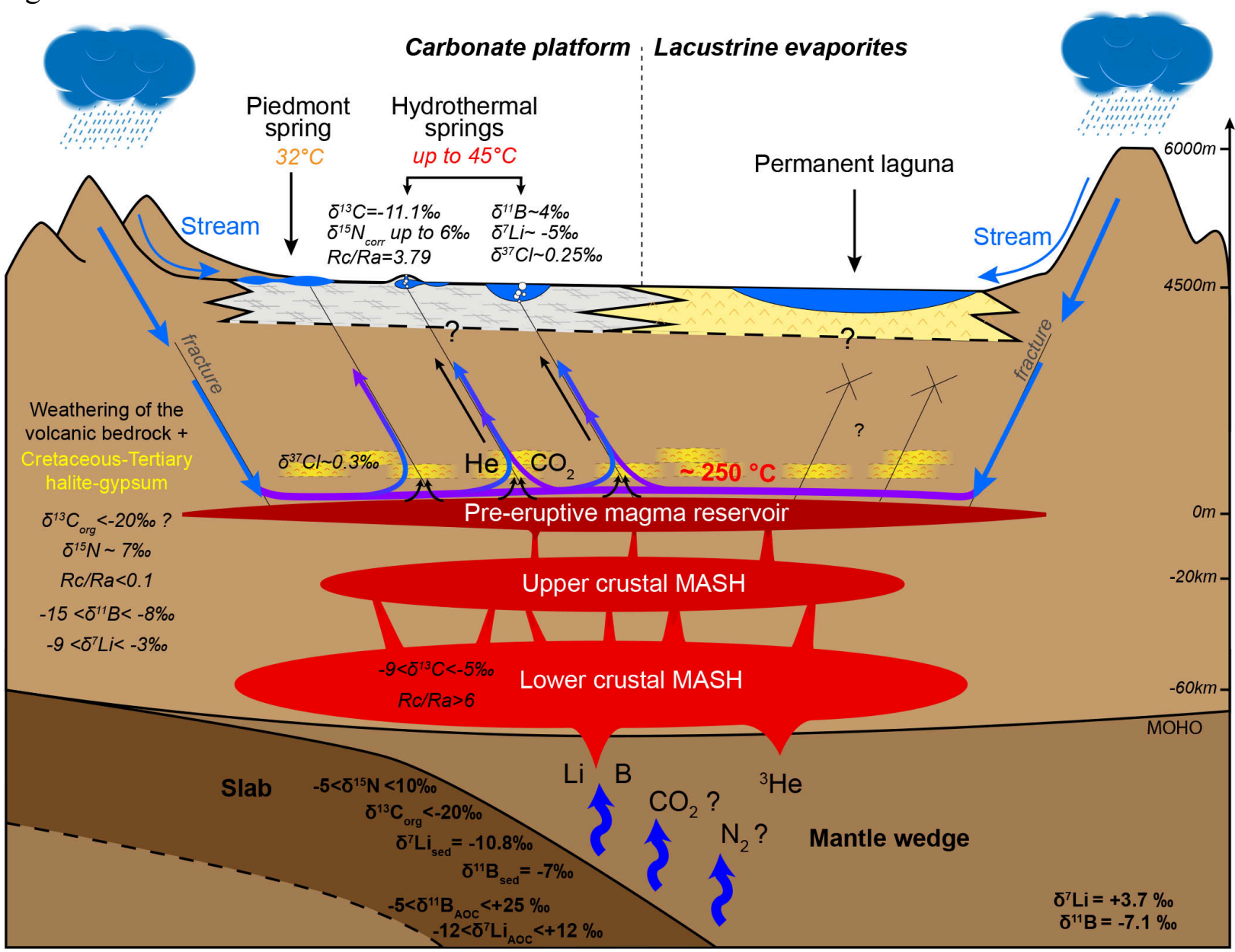




\section{A Multi-Tracers Analysis of Gas and Solutes in Laguna Pastos Grandes (Bolivia): Key} Proxies of the Origin of Continental Carbonates in Andean Salars ${ }^{4}$ IFP Energies Nouvelles, 1-4 Avenue de Bois Préau, 92852, Rueil-Malmaison Cedex, France

\section{Analytical methods}

$\mathbf{N}_{2}$ gas: $\delta^{15} \mathrm{~N}$ of $\mathrm{N} 2$ gas was measured following the protocol of Li et al. (2009). Purification starts with a cryogenic separation at liquid nitrogen temperature. The noncondensable gases, including $\mathrm{N}_{2}, \mathrm{H}_{2}, \mathrm{O}_{2}, \mathrm{CH}_{4}$ and $\mathrm{He}$, are inserted in the line and circulated using a mercury Toeppler pump through a $\mathrm{CuO}$ reactor maintained at $950{ }^{\circ} \mathrm{C}$ for 30 minutes (and then cooled to $450{ }^{\circ} \mathrm{C}$ ) to oxidize $\mathrm{H}_{2}$ and $\mathrm{CH}_{4}$. The resulting $\mathrm{CO}_{2}$ and $\mathrm{H}_{2} \mathrm{O}$ are cryogenically trapped at liquid-nitrogen boiling temperature. Excess $\mathrm{O}_{2}$, if any, is resorbed and the NOx that was potentially generated during the previous oxidation phase is reduced to $\mathrm{N}_{2}$ by circulating the gases over a $\mathrm{Cu}$ reactor maintained at $600{ }^{\circ} \mathrm{C}$. The purified $\mathrm{N}_{2}$ and $\mathrm{He}$ are then collected with the mercury Toeppler pump and manometrically quantified before being transferred in vials for measurement using a dual-inlet IRMS Delta + XP. This instrument is calibrated by measuring an internal reference $\mathrm{N}_{2}$ gas, itself calibrated against the air, the international reference standard for $\delta^{15} \mathrm{~N}$ measurements, which has by definition an absolute value of $\delta^{15} \mathrm{~N}_{\text {Air }}=0 \%$. The $\mathrm{CO}_{2}$ that was trapped using liquid nitrogen was then released at $-140{ }^{\circ} \mathrm{C}$, collected using a liquid $\mathrm{N}_{2}$ trap and manometrically quantified before being transferred to vials for measurement using the dual-inlet IRMS Delta + XP. $\delta^{13} \mathrm{C}$ values compare well with those obtained by GC/C/IRMS at the IFPEN laboratory (mean difference $<0.2 \%$; Table A1).

Noble gas: Noble gases were measured following the protocol of Moreira et al. (2018). The gas purification consists of several combustions: the first one with a Bulk Getter (SAES) heating system maintained at $400{ }^{\circ} \mathrm{C}$ for 5 minutes, followed by two 5minute combustions at $800{ }^{\circ} \mathrm{C}$ each with titanium sponge. After purification, helium is separated from the other noble gases using activated charcoal at $30 \mathrm{~K}$, introduced into the Helix-SFT mass spectrometer and analyzed using peak jumping. ${ }^{3} \mathrm{He}$ is collected on the electron multiplier in pulse-counting mode whereas ${ }^{4} \mathrm{He}$ is analyzed on the Faraday cup and the signal is amplified using either $10^{11} \mathrm{ohm}$ or $10^{12} \mathrm{ohm}$ resistance depending on the signal. After the helium was measured, neon is released from the cold trap at $70 \mathrm{~K}$. Two 
cycles of neon isotope measurement are performed before neon is introduced to stabilize the magnet. For each cycle, ${ }^{20} \mathrm{Ne}$ is measured using a mass-scan instead of setting the magnet on the required field to measure ${ }^{20} \mathrm{Ne}$ (see Moreira et al., 2018 for details). ${ }^{21} \mathrm{Ne}$, partially desorbed at $130 \mathrm{~K}$ and transferred to charcoal at the temperature of liquid nitrogen for 15 minutes. After the desorption of argon at room temperature from the charcoal trap, dilution(s) using a $1 \mathrm{~L}$ reservoir is/are used to decrease the amount of argon introduced into the mass spectrometer. ${ }^{36} \mathrm{Ar}$ and ${ }^{38} \mathrm{Ar}$ are collected on the electron multiplier, whereas ${ }^{40} \mathrm{Ar}$ is measured on the Faraday cup using $10^{11} \mathrm{ohm}$ resistance. All the data were corrected following the procedure of Moreira et al. (2018).

B isotopes: $\delta^{11} \mathrm{~B}$ was measured in rock samples following the protocol of Chetelat et al. (2009). Finely powdered sample $(50 \mathrm{mg})$ was admixed with $300 \mathrm{mg}$ of ultra-pure $\mathrm{K}_{2} \mathrm{CO}_{3}$ in a Pt crucible and melted in a muffle furnace at $950{ }^{\circ} \mathrm{C}$ for 15 minutes. The pellet was taken up in $3 \mathrm{~mL}$ of $0.5 \mathrm{HNO}_{3}$ and added to a $50 \mathrm{~mL}$ vial filled with $20 \mathrm{~mL} \mathrm{H}_{2} \mathrm{O}$. An additional $1-2 \mathrm{~mL}$ of $0.5 \mathrm{~N} \mathrm{HNO}_{3}$ were added until complete dissolution. The final $\mathrm{pH}$ was adjusted to $\mathrm{pH} 1.7$ with $3 \mathrm{~N} \mathrm{HNO}_{3}$, and $7 \mathrm{~mL}$ of this solution were passed through $2 \mathrm{~mL}$ of the cation exchange resin AG 50W-X8 to extract most of the cationic load. The recovered solution was adjusted to $\mathrm{pH} 8-9$ with distilled $4 \mathrm{~N} \mathrm{NH}_{4} \mathrm{OH}$ and $\mathrm{B}$ was extracted on Amberlite IRA-743 resin in two steps: the first step consisted of extraction on a column loaded with $300 \mu \mathrm{L}$ of resin and the second step of purification (after adjustment to $\mathrm{pH} 8$ 9 again) on a column filled with $50 \mu \mathrm{L}$ of the resin.

\section{Geothermometric calculations}

The silica concentration of our samples is fairly uniform within the range of 101 to 154 $\mathrm{mg} / \mathrm{l}$ (Table 2). Applying the quartz geothermometer described in Kharaka and Mariner (1989), Verma and Santoyo $(1995,1997)$ estimated equilibrium temperatures of spring water with the rocks of a deep reservoir up to $163 \pm 3^{\circ} \mathrm{C}$ (assuming no steam loss; Table A3) with a mean of $149 \pm 11^{\circ} \mathrm{C}$. However, considering the temperature between the surface and the deep reservoir, the strong influence of temperature on quartz solubility as well as precipitation of silica during water cooling as it ascends to the surface could affect the estimated temperature. The Na-K-Ca geothermometer yields similar estimates $(156 \pm 30$ ${ }^{\circ} \mathrm{C}$ ) when the $\mathrm{Mg}$ correction of Fournier and Potter (1979) is applied. But similarly, this geothermometer calibrated on silicates can also be affected by a precipitation of silicates during the cooling of the thermal water.

The Na-Li geothermometer gives much higher estimates (around $300^{\circ} \mathrm{C}$ ) regardless of the equation used (Fouillac and Michard, 1981; Kharaka et al., 1982; Verma and Santoyo, 1993, 1997). Using a larger dataset than in the previous articles, Sanjuan et al. (2014) modified the equations of Kharaka et al. (1982) and Fouillac and Michard (1981). Their corrections do not modify the results for the Kharaka et al. equation (mean value $325^{\circ} \mathrm{C}$ ) and decrease the values obtained with the Fouillac and Michard equation (mean value 251 ${ }^{\circ} \mathrm{C}$ ) by $50{ }^{\circ} \mathrm{C}$. The Li-Mg geothermometer (Kharaka and Mariner, 1989) yields lower values $\left(186 \pm 18{ }^{\circ} \mathrm{C}\right.$; Table A3) than the Na-Li geothermometer. The discrepancies observed between the geothermometers using $\mathrm{Li}$ can be explained by the high concentrations of $\mathrm{Li}$ in our samples. The $\log (\mathrm{Na} / \mathrm{Li})$ values obtained for the thermal springs of Laguna Pastos Grandes are between 1.24 and 1.47 whereas the values used by Sanjuan et al. (2014) for their calibrations are never lower than 2.00. Consequently, our 
1175

1176

1177

1178

1179

1180

1181

1182

1183

1184

1185

1186

1187

1188

1189

1190

1191

1192

1193

1194

1195

1196

1197

1198

1199

1200

1201

1202

1203

1204

1205

1206

1207

1208

1209

1210

1211

1212

1213

1214

1215

1216

1217

1218

1219

1220

1221

1222

data are not in the range of calibration of the equations and if the correlations cannot be extended linearly, the uncertainties on the calculated temperatures will be high.

The geothermometer based on $\mathrm{Li}$ isotopes was also tested as it is independent from the $\mathrm{Li}$ concentration. This geothermometer was calibrated experimentally on springs from the Guadeloupe and Martinique volcanic arcs (Millot et al., 2010). It relies on the fact that Li isotopic fractionation $\left(\Delta_{\text {solution-solid }}\right)$ between solution and basalt is strongly temperature dependent with, for example, values of $+19.4 \%$ at $25{ }^{\circ} \mathrm{C}$ to $6.7 \%$ at $250{ }^{\circ} \mathrm{C}$. Considering the $\delta^{7} \mathrm{Li}$ mean value of $4.44 \pm 0.90 \%$ for thermal springs and using the values for rhyolitic ignimbrite, dacite and andesite in the area that are reported in Table 3, we obtained a

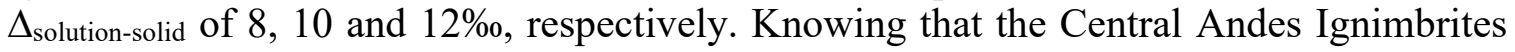
are a 50:50 mixture of mantle-derived basalts and of regional crust (de Silva and Kay, 2018), we can hypothesize that the behavior of $\mathrm{Li}$ in these rocks and in the altered products is not very different from that in the andesite of Guadeloupe. In this case, the calibration temperature of Millot et al. (2010) for fractionations between 8 and 12\%o would give a temperature of $200 \pm 25^{\circ} \mathrm{C}$. The Na-K geothermometer yields similar estimates of $228 \pm 9$ ${ }^{\circ} \mathrm{C}$ with the equation of Verma and Santoyo (1997) and $205 \pm 12{ }^{\circ} \mathrm{C}$ with that of Santoyo and Diaz-Gonzalez (2010).

\section{PHREEQC modeling:}

The mineralogical composition of the volcanic rocks sampled around the Laguna Pastos has been determined by DRX as:

- Dacite: alkali and potassium feldspar, quartz, biotite

- Andesite: alkali feldspar, biotite, olivine, amphibole

- Ignimbrite: alkali and potassium feldspar, quartz, biotite, amphibole

As numerous of these minerals are not available in the Thermoddem database, we

performed the PHREEQC modeling with the selected minerals as follows:

\section{Solution 1}

units $\mathrm{mmol} / \mathrm{l}$

temp 225 \# Temperature varying between 200 and $250^{\circ} \mathrm{C}$

Equilibrium_phases 1

Quartz(alpha) $0.0 \quad 10.0$

Sanidine $\quad 0.0 \quad 10.0$

Albite(low) $\quad 0.0 \quad 10.0$

Anorthite $\quad 0.0 \quad 10.0$

Pargasite $\quad 0.0 \quad 10.0$

Anhydrite $\quad 0.0 \quad 10.0$

CO2 $(g) \quad$ \#CO2 $(g)$ SI varying between $1-2$

End spring water

\section{References}

Fouillac C. and Michard G. (1981) Sodium/lithium ratio in water applied to geothermometry of geothermal reservoirs. Geothermics 10(1), 55-70.

Fournier R. O. and Potter Ii R. W. (1979) Magnesium correction to the Na/K/Ca chemical geothermometer. Geochimica et Cosmochimica Acta 43(9), 1543-1550.

Kharaka Y. K., Lico M. S. and Law L. M. (1982) Chemical geothermometers applied to formation waters, Gulf of Mexico and California basins. AAPG Bulletin 66(5), 588-588. 
1223 Kharaka Y. K. and Mariner R. H. (1989) Chemical geothermometers and their

1224 application to formation waters from sedimentary basins. In Thermal history of

1225 sedimentary basins. Springer, New York, NY. pp. 99-117.

1226 Verma S. P. and Santoyo E. (1995) New improved equations for $\mathrm{Na} / \mathrm{K}$ and $\mathrm{SiO}_{2}$

1227 geothermometers by error propagation. Proc. World Geotherm. Congr 2, 963-968.

\section{Figure captions}

1230 Figure A1. Photography and illustrating schema of bubbling gas sampling method.

1231 Figure A2. Comparison of the water composition obtained for the volcanic bedrock weathering at 200 (blue), 225 (red) and $250{ }^{\circ} \mathrm{C}$ (green) with increasing $\mathrm{pCO}_{2}$ from 10 bar in light color to 100 bar in dark color. The average spring water is in black.

1234 Figure A3. Air-normalized helium R/Ra values plotted against $\mathrm{He} / \mathrm{Ne}$ ratios of gas samples 1235 from Laguna Pastos Grandes compared with other Andean sources (Hoke et al., 1994). 1236 Mixing lines between the three main sources of helium (crustal CRUST, mantle MORB and air saturated water ASW) are also represented.

Figure A4. Relations between chloride and sodium for Pastos Grandes brines (in yellow) and water sources as a function of temperature: thermal spring $>35^{\circ} \mathrm{C}$ in red, $<32{ }^{\circ} \mathrm{C}$ in orange and cold stream $<15{ }^{\circ} \mathrm{C}$ in blue. Na-Cl compositions are compared with other Bolivian salars (pale triangles; Risacher and Fritz, 1991). Data from this study are reported with dots and previous data with squares (Ballivian and Risacher, 1981; Hurlbert and Chang, 1984; Risacher and Fritz, 1991; Jones and Renaut, 1994). 
1246 Table A1. Detailed nitrogen and carbon isotopic analysis of gas samples from Laguna 1247 Pastos Grandes.

\begin{tabular}{|crlcc|}
\hline \multicolumn{5}{|c|}{ Nitrogen analysis } \\
\hline Sample & Date & Method & $\delta^{15} \mathrm{~N}(\%)$ & $1 \sigma$ \\
\hline PG100 & $20 / 07 / 2017$ & GC-IRMS on steel tube & 2.73 & 0.03 \\
PG100 & $20 / 07 / 2017$ & GC-IRMS on steel tube & 2.75 & 0.01 \\
PG112 & $20 / 07 / 2017$ & GC-IRMS on steel tube & 1.79 & 0.02 \\
PG112 & $20 / 07 / 2017$ & GC-IRMS on steel tube & 1.77 & 0.01 \\
PG112 & $07 / 02 / 2018$ & GC-IRMS on exetainer & 1.74 & 0.02 \\
PG116 & $07 / 02 / 2018$ & GC-IRMS on exetainer & 1.60 & 0.02 \\
PG117 & $19 / 07 / 2017$ & GC-IRMS on steel tube & 2.49 & 0.05 \\
PG117 & $19 / 07 / 2017$ & GC-IRMS on steel tube & 2.47 & 0.03 \\
PG117 & $19 / 07 / 2017$ & GC-IRMS on steel tube & 2.24 & 0.03 \\
PG117 & $19 / 07 / 2017$ & GC-IRMS on steel tube & 2.26 & 0.02 \\
PG117 & $19 / 07 / 2017$ & GC-IRMS on steel tube & 2.18 & 0.02 \\
PG117 & $19 / 07 / 2017$ & GC-IRMS on steel tube & 2.17 & 0.02 \\
\hline & \multicolumn{5}{c}{ Carbon analysis } & & \\
\hline Sample & Date & Method & $\delta^{13}$ C $(\%)$ & $1 \sigma$ \\
\hline PG100 & $14 / 06 / 2017$ & GC-C-IRMS & -11.36 & 0.01 \\
PG100 & $14 / 06 / 2017$ & GC-C-IRMS & -11.32 & 0.01 \\
PG100 & $14 / 06 / 2017$ & GC-C-IRMS & -11.31 & 0.01 \\
PG100 & $20 / 07 / 2017$ & GC-IRMS & -10.73 & 0.03 \\
PG100 & $20 / 07 / 2017$ & GC-IRMS & -11.27 & 0.03 \\
PG112 & $14 / 06 / 2017$ & GC-C-IRMS & -11.31 & 0.01 \\
PG112 & $14 / 06 / 2017$ & GC-C-IRMS & -11.24 & 0.01 \\
PG112 & $14 / 06 / 2017$ & GC-C-IRMS & -11.26 & 0.01 \\
PG112 & $20 / 07 / 2017$ & GC-IRMS & -11.11 & 0.03 \\
PG112 & $20 / 07 / 2017$ & GC-IRMS & -11.24 & 0.03 \\
PG116 & $14 / 06 / 2017$ & GC-C-IRMS & -11.25 & 0.03 \\
PG116 & $14 / 06 / 2017$ & GC-C-IRMS & -11.08 & 0.03 \\
PG116 & $14 / 06 / 2017$ & GC-C-IRMS & -11.05 & 0.03 \\
PG116 & $07 / 02 / 2018$ & GC-IRMS & -11.00 & 0.04 \\
PG116 & $07 / 02 / 2018$ & GC-IRMS & -11.49 & 0.04 \\
PG116 & $07 / 02 / 2018$ & GC-IRMS & -11.43 & 0.06 \\
PG117 & $14 / 06 / 2017$ & GC-C-IRMS & -11.06 & 0.04 \\
PG117 & $19 / 07 / 2017$ & GC-IRMS & -10.85 & 0.05 \\
\hline & & & & \\
\hline
\end{tabular}


1248 Table A2. Stable isotope compositions of Andean salars water, rainfall and snow from the region of Pastos Grandes (from this study* and Boschetti et al., 2007).

\begin{tabular}{|lcc|}
\hline & $\delta^{18} \mathrm{O}( \pm 0.1 \%, 1 \mathrm{~s})$ & $\delta \mathrm{D}( \pm 0.8 \%, 1 \mathrm{~s})$ \\
\hline Chaxa lagoon & -0.8 & -30.5 \\
Miñique lagoon & 5.4 & 10.1 \\
Miscanti lagoon & 3.3 & 0.5 \\
Uyuni* & 1.9 & -26.1 \\
Rainfall* & -16.3 & -112.9 \\
Snow 1* & -6.8 & -30.3 \\
Snow 2* & -2.7 & 6.5 \\
\hline
\end{tabular}

Table A3. Estimated equilibrium temperatures $\left({ }^{\circ} \mathrm{C}\right)$ for hydrothermal sources obtained with different geothermometers.

\begin{tabular}{|c|c|c|c|c|c|c|c|}
\hline Geothermometer & PG_117 & PG_112 & PG_100 & PG1_1 & MV_1 & PGS_1 & Mean \\
\hline $\mathrm{SiO}_{2}$ (Verma and Santoyo, 1997) & 145 & 138 & 145 & $1 \overline{6} 3$ & $1 \overline{6} 2$ & $1 \overline{3} 8$ & 149 \\
\hline $\mathrm{Na} / \mathrm{K} / \mathrm{Ca}-\mathrm{Mg}$ (Fournier and Potter, 1979) & 177 & 144 & 169 & 167 & 171 & 107 & 156 \\
\hline $\mathrm{Na} / \mathrm{K}$ (Verma and Santoyo, 1997) & 215 & 226 & 237 & 222 & 230 & 240 & 228 \\
\hline d Diaz-Gonz & 188 & 202 & 216 & 197 & 221 & 207 & 205 \\
\hline id Michard, 1 & 315 & 316 & 344 & 272 & 283 & 268 & 300 \\
\hline y Sanjuan et al., 2014) & 264 & 264 & 285 & 230 & 239 & 226 & 251 \\
\hline and Santove 1097) & 323 & 324 & 351 & 280 & 292 & 276 & 308 \\
\hline $\mathrm{Na} /$ & 33 & 335 & 35 & 304 & 312 & 301 & 323 \\
\hline $\mathrm{Na} / \mathrm{Li}$ (modified by Sanjuan et al., 2014) & 336 & 337 & 355 & 306 & 314 & 303 & 325 \\
\hline Mg/Li (Kharaka and Mariner, 1989) & 199 & 193 & 197 & 185 & 192 & 151 & 186 \\
\hline
\end{tabular}

1253 Table A4. $\delta^{37} \mathrm{Cl}$ analyses of water samples from Laguna Pastos Grandes.

\begin{tabular}{|lcc|}
\hline Sample & $\delta^{37} \mathrm{Cl}(\%)$ & $1 \sigma$ \\
\hline La Salsa 1 & 0.308 & 0.002 \\
La Salsa 2 & 0.230 & 0.010 \\
La Salsa 3 & 0.230 & 0.009 \\
La Salsa 4 & 0.260 & 0.009 \\
La Salsa 5 & 0.234 & 0.003 \\
La Salsa 6 & 0.292 & 0.002 \\
La Salsa 7 & 0.300 & 0.002 \\
La Rumba 1 & 0.227 & 0.010 \\
La Rumba 2 & 0.205 & 0.006 \\
La Rumba 3 & 0.234 & 0.011 \\
El Ojo Verde 1 & 0.246 & 0.009 \\
El Ojo Verde 2 & 0.252 & 0.013 \\
\hline Average & $\mathbf{0 . 2 5 1}$ & $\mathbf{0 . 0 3 2}$ \\
\hline
\end{tabular}


1255 Table A5. Results of PHREEQC modeling. Alb. Albite(low); Anh. Anhydrite; An. Anorthite;

1256 Hal. Halite; Par. Pargasite; Qtz. Quartz(alpha); San. Sanidine

\begin{tabular}{|c|c|c|c|c|c|c|c|c|c|c|c|c|c|c|c|}
\hline & $\begin{array}{c}\mathrm{pCO}_{2} \\
\text { (bar) }\end{array}$ & & lh & nh. & $n$ & $\mathrm{O} 2(\mathrm{~g})$ & Hal. & $\operatorname{ar}$ & 2 tz & San & & C & $\mathrm{Ca}$ & 1 & \\
\hline \multirow{6}{*}{ 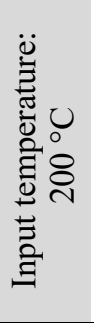 } & 10 & & & $-5.0 \mathrm{E}-4$ & $7 \mathrm{E}-2$ & $-1.0 \mathrm{E}-1$ & $-2.4 \mathrm{E}-1$ & & -7.6 & & \multirow{18}{*}{ 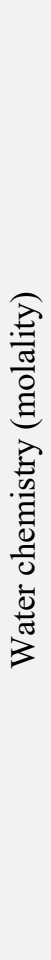 } & & & 2.4 & \\
\hline & 20 & & $5.0 \mathrm{E}-2$ & $-5.3 \mathrm{E}-4$ & $-1.6 \mathrm{E}-2$ & $-2.0 \mathrm{E}-1$ & $-2.4 \mathrm{E}-1$ & $-2.4 \mathrm{E}-3$ & $-7.6 \mathrm{E}-2$ & $-1.1 \mathrm{E}-2$ & & $.0 \mathrm{E}-1$ & $1 \mathrm{E}-2$ & $2.4 \mathrm{E}-1$ & \\
\hline & 40 & $\stackrel{\text { }}{\frac{2}{\pi}}$ & $5.2 \mathrm{E}-2$ & $-5.7 E-4$ & $1.4 \mathrm{E}-2$ & $-3.9 \mathrm{E}-1$ & $-2.4 \mathrm{E}-1$ & $-4.4 \mathrm{E}-3$ & $-7.4 \mathrm{E}-2$ & $-1.1 \mathrm{E}-2$ & & $.9 \mathrm{E}-1$ & $2.3 \mathrm{E}-2$ & $2.4 \mathrm{E}-1$ & 1.14 \\
\hline & 60 & 。̈ & $5.4 \mathrm{E}-2$ & $-6.0 \mathrm{E}-4$ & $12 \mathrm{~F}-2$ & $-58 F_{-} 1$ & $-24 F_{-}-1$ & $63 \mathrm{~F}^{2} 3$ & $-72 \mathrm{~F}-2$ & $11 \mathrm{~F}_{-} ?$ & & $5.8 \mathrm{E}-1$ & $2.5 \mathrm{E}-2$ & $2.4 \mathrm{E}-1$ & \\
\hline & 80 & & $5.5 \mathrm{E}-2$ & $-6.3 \mathrm{E}-4$ & $-9.9 \mathrm{E}-3$ & $-7.6 \mathrm{E}-1$ & $-2.4 \mathrm{E}-1$ & $-8.1 \mathrm{E}-3$ & $-6.9 \mathrm{E}-2$ & $-1.1 \mathrm{E}-2$ & & $7.6 \mathrm{E}-1$ & $2.7 \mathrm{E}-2$ & $2.4 \mathrm{E}-1$ & \\
\hline & 100 & - & $5.7 \mathrm{E}-2$ & $-6.6 \mathrm{E}-4$ & $-7.8 \mathrm{E}-3$ & $-9.6 \mathrm{E}-1$ & $-2.4 \mathrm{E}-1$ & $-1.0 \mathrm{E}-2$ & $-6.7 \mathrm{E}-2$ & $-1.1 \mathrm{E}-2$ & & $9.6 \mathrm{E}-1$ & 2.9 & 2.4 & \\
\hline \multirow{6}{*}{ 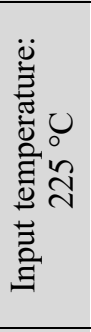 } & 1 & & $3.6 \mathrm{E}-$ & $-4.5 E-4$ & $\mathrm{~F}$ & 10 & $-24 \mathrm{~F}$ & & -4.7 & & & & & & \\
\hline & 20 & 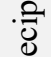 & $3.6 \mathrm{E}-2$ & $-4.7 E-4$ & $-8.9 \mathrm{E}-3$ & $-2.0 \mathrm{E}-$ & $-2.4 \mathrm{E}$ & -1 . & & & & & & & \\
\hline & 40 & 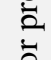 & $3.7 \mathrm{E}-2$ & $-4.9 \mathrm{E}-4$ & $-8.1 \mathrm{E}-3$ & $-4.0 \mathrm{E}-$ & $-2.4 \mathrm{E}$ & -1.9 & $-4.5 \mathrm{I}$ & $-1.5 \mathrm{H}$ & & & & 2.4 & \\
\hline & 60 & I & $3.7 \mathrm{E}-2$ & $-5.1 \mathrm{E}-4$ & - & -6.0 & -2.4 & & & & & & & & \\
\hline & 80 & 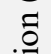 & $3.8 \mathrm{E}-2$ & $-5.2 \mathrm{E}-4$ & $-6.3 \mathrm{E}-3$ & $-7.9 \mathrm{E}-1$ & $-2.4 \mathrm{E}-1$ & $-3.4 \mathrm{E}-3$ & $-4.3 E-2$ & $-1.5 \mathrm{E}-2$ & & $7.9 \mathrm{E}-1$ & $1.4 \mathrm{E}-2$ & $2.4 \mathrm{E}-1$ & 1.5 \\
\hline & 100 & & $3.8 \mathrm{E}-2$ & $-5.4 \mathrm{E}-4$ & $-5.4 \mathrm{E}-3$ & $-9.9 \mathrm{E}-1$ & $-2.4 \mathrm{E}-1$ & $-4.2 \mathrm{E}-3$ & $-4.1 \mathrm{E}-2$ & $-1.5 \mathrm{E}-2$ & & $1.0 \mathrm{E} 0$ & $1.4 \mathrm{E}-2$ & $2.4 \mathrm{E}-1$ & 1.0 \\
\hline \multirow{6}{*}{ 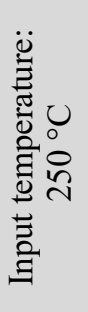 } & 10 & $\bar{\sigma}$ & $3.2 \mathrm{E}-2$ & $-4.3 \mathrm{E}-4$ & $-5.8 \mathrm{E}-3$ & $-1.1 \mathrm{E}-1$ & $-2.4 \mathrm{E}-1$ & $-3.0 \mathrm{E}-4$ & $-3.1 \mathrm{E}-2$ & $-1.9 \mathrm{E}-2$ & & $1.10-1$ & 0.0 & 2.7 & \\
\hline & 20 & 4 & $3.2 \mathrm{E}-2$ & $-4.4 \mathrm{E}-4$ & $-5.6 \mathrm{E}-3$ & $-2.2 \mathrm{E}-1$ & $-2.4 \mathrm{E}-1$ & $-5.0 \mathrm{E}-4$ & $-3.1 \mathrm{E}-2$ & $-1.9 \mathrm{E}-2$ & & $2.2 \mathrm{E}-1$ & $7.0 \mathrm{E}-3$ & 2.41 & \\
\hline & 40 & 节 & $3.2 \mathrm{E}-2$ & $-4.5 \mathrm{E}-4$ & $-5.2 \mathrm{E}-3$ & $-4.5 \mathrm{E}-1$ & $-2.4 \mathrm{E}-1$ & $-8.6 \mathrm{E}-4$ & $-3.0 \mathrm{E}-2$ & $-1.9 \mathrm{E}-2$ & & & & $2.7 \mathrm{~L}$ & \\
\hline & 60 & 岂 & $3.3 \mathrm{E}-2$ & $-4.6 \mathrm{E}-4$ & $-4.8 \mathrm{E}-3$ & $-6.7 \mathrm{E}-1$ & $-2.4 \mathrm{E}-1$ & $-1.2 \mathrm{E}-3$ & $-3.0 \mathrm{E}-2$ & $-1.9 \mathrm{E}-2$ & & $6.7 \mathrm{E}-1$ & $7.6 \mathrm{E}-3$ & $2.4 \mathrm{E}-1$ & 1.9 \\
\hline & 80 & & $3.3 \mathrm{E}-2$ & $-4.7 E-4$ & $-4.4 \mathrm{E}-3$ & $-8.8 \mathrm{E}-1$ & $-2.4 \mathrm{E}-1$ & $-1.5 \mathrm{E}-3$ & $-2.9 \mathrm{E}-2$ & $-1.9 \mathrm{E}-2$ & & $8.9 \mathrm{E}-1$ & $7.9 \mathrm{E}-3$ & $2.4 \mathrm{E}-1$ & \\
\hline & 100 & & $3.3 \mathrm{E}-2$ & $-4.7 \mathrm{E}-4$ & $-4.0 \mathrm{E}-3$ & -1.1E0 & $-2.4 \mathrm{E}-1$ & $-1.8 \mathrm{E}-3$ & $-2.9 \mathrm{E}-2$ & $-1.9 \mathrm{E}-2$ & & 1.1E0 & $8.2 \mathrm{E}-3$ & $2.4 \mathrm{E}-1$ & \\
\hline
\end{tabular}


Table A6. Comparison of Laguna Pastos Grandes characteristics with Chilean and Bolivian salars. Data from this study and Hoke et al., 1994; Spiro et al., 1997; Risacher et al., 2003, 2011; Risacher and Fritz, 1991, 2009. ul: ulexite; hal: halite; gyps: gypsum; mirab: mirabilite. *Previous data TDS: Total Dissolved Solids

Laguna Pastos Grandes

\begin{tabular}{|lr}
\hline $\begin{array}{lr}\text { Location } \\
\text { Basement }\end{array}$ & $\begin{array}{r}\text { Bolivian Altiplano } \\
\text { Dacite-Andesite- } \\
\text { Rhyolitic Ignimbrite }\end{array}$ \\
Altitude & $4450 \mathrm{~m}$ \\
Surface & $130 \mathrm{~km}^{2}$ \\
Potential evaporation & $1400 \mathrm{~mm} /$ year \\
Precipitation & $100 \mathrm{~mm} /$ year \\
Mean temperature & $5{ }^{\circ} \mathrm{C}$ \\
Morphology & Playa lake \\
Salinity & $256 \mathrm{~g} / 1$ \\
Brine type $(\mathrm{Na}-\mathrm{Cl}$-) & $\mathrm{Ca}$ \\
Salts & $\mathrm{Calcite-gyps.-ul.-hal.}$ \\
Infiltration rate & $\sim$ negligible \\
Thermal influence $\left(\mathrm{T}>15^{\circ} \mathrm{C}\right)$ & $\mathrm{Yes}$ \\
Spring Tmax & $47^{\circ} \mathrm{C}\left(20-75{ }^{\circ} \mathrm{C} *\right)$ \\
Spring TDS (range) & $14 \mathrm{~g} / 1$ \\
$\mathrm{Mantle}^{*}$ influence & $47 \%$ \\
$\mathrm{CO}_{2}$ isotopic composition & $-11 \% 0$ \\
\hline
\end{tabular}

\section{Chilean salars}

Western Cordillera Rhyolitic ignimbrite

Andesite 3400-4300 m $0.03-400 \mathrm{~km}^{2}$ $1000-2000 \mathrm{~mm} /$ year 40-380 $\mathrm{mm} /$ year $0{ }^{\circ} \mathrm{C}$

Mainly playa lakes $1.2-365 \mathrm{~g} / 1$ $65 \% \mathrm{sO} 4-24 \% \mathrm{Ca}$ Gyps.-hal.-mirab.-ul. $0.01-12.8 \%$ of outflow $78 \%$

$83{ }^{\circ} \mathrm{C}$ (Puchuldiza) $3.8 \mathrm{~g} / \mathrm{l}$ in average $(0.2-21.8)$ $69 \%$ -8 to $-0.6 \%$

\section{Bolivian salars}

Bolivian Altiplano
Andesite
Rhyodacite
$4100-4600 \mathrm{~m}$
$0.03-500 \mathrm{~km}^{2}$
$1000-1500 \mathrm{~mm} /$ year
$50-150 \mathrm{~mm} /$ year
$5-10{ }^{\circ} \mathrm{C}$
Mainly playa lakes
$0.4-348 \mathrm{~g} / 1$
$52 \%$ sO4 - 26\% CO3 - $19 \% \mathrm{Ca}$
Gyps.-hal.-mirab.-ul.
$0.01 \%-\sim$ inflows
$60 \%$
$36{ }^{\circ} \mathrm{C}(\mathrm{Challviri})$
$0.82 \mathrm{~g} / \mathrm{l}$ in average (max. 14$)$
$44 \%$
-20 to $-6 \% \mathrm{o}$

